\title{
Against the Thalassocracy: Sacred Geography, Nationhood and Perennial Traditionalism in Alexander Dugin's Neo-Eurasianist Philosophy
}

Jonathan Rushbrook

Follow this and additional works at: https://researchrepository.wvu.edu/etd

\section{Recommended Citation}

Rushbrook, Jonathan, "Against the Thalassocracy: Sacred Geography, Nationhood and Perennial Traditionalism in Alexander Dugin's Neo-Eurasianist Philosophy" (2015). Graduate Theses, Dissertations, and Problem Reports. 6542.

https://researchrepository.wvu.edu/etd/6542

This Thesis is protected by copyright and/or related rights. It has been brought to you by the The Research Repository @ WVU with permission from the rights-holder(s). You are free to use this Thesis in any way that is permitted by the copyright and related rights legislation that applies to your use. For other uses you must obtain permission from the rights-holder(s) directly, unless additional rights are indicated by a Creative Commons license in the record and/ or on the work itself. This Thesis has been accepted for inclusion in WVU Graduate Theses, Dissertations, and Problem Reports collection by an authorized administrator of The Research Repository @ WVU. For more information, please contact researchrepository@mail.wvu.edu. 


\title{
Against the Thalassocracy: Sacred Geography, Nationhood and Perennial Traditionalism in Alexander Dugin's Neo-Eurasianist Philosophy
}

\author{
Jonathan Rushbrook \\ Thesis submitted \\ to the Eberly College of Arts and Sciences \\ at West Virginia University \\ in partial fulfillment of the requirements for the degree of \\ Master of Art in \\ History
}

\author{
Robert Blobaum, Ph.D., Chair \\ Mark Tauger, Ph.D. \\ Joshua Arthurs, Ph.D. \\ Department of History
}

\section{Morgantown, West Virginia 2013}

Keywords: Neo-Eurasianism, Fascism, Nationalism, Racism, Perennial Tradition, Alexander Dugin, Julius Evola, Identity, European New Right 


\author{
ABSTRACT \\ Against the Thalassocracy: Sacred Geography, Nationhood and Perennial \\ Traditionalism in Alexander Dugin's Neo-Eurasianist Philosophy
}

\begin{abstract}
Jonathan Rushbrook
This thesis discusses the ideological makeup of the Russian right wing philosopher Alexander Dugin and his conceptualization of race and nation in his Neo-Eurasianist imperial project. Tracing Dugin's ideological influences from early Eurasianism, the European New Right and esoteric religious beliefs such as Perennial Traditionalism, the thesis then goes on to place Dugin's body of thought within a larger debate on defining fascism and whether Dugin can be considered a fascist. Ultimately this thesis contests some scholars' interpretations of Dugin's worldview as a fundamentally ethnocentric or even racist Russian nationalism. Rather, by examining Dugin's writings on nation through an ethno-symbolist prism this thesis argues that Dugin holds a fundamentally religious understanding of reality that sees nations as manifestations of a spiritual, rather than a biological, essence. Thus it precludes Dugin from any purely biological racism. Concomitantly, the thesis emphasizes that Dugin's NeoEurasianist imperial project disqualifies him from any typical fascist taxonomy. Instead, NeoEurasianism represents a genuinely unique strain of extreme right wing thought that, though shares many similarities with historic fascism, nonetheless cannot be considered fascist due to Dugin's profoundly anti-modern vision and the supranational emphasis of his imperial objectives.
\end{abstract}


Table of Contents

Introduction .................................................................................................. 1

Methodology and Sources ............................................................................................. 7

Literature Review ..................................................................................... 9

Theoretical Framework............................................................................... 15

Chapter 1: Alexander Dugin: His Political Life and Ideas....................................... 28

Chapter 2: Early Eurasianism, Lev Gumilev and the French Nouvelle Droite ....... 36

Chapter 3: Perennial Traditionalism and Dugin's Neo-Eurasianism..................... 56

Chapter 4: Dugin, Race and the Racist New Right .............................................. 67

Chapter 5: Dugin and Fascism..................................................................... 73

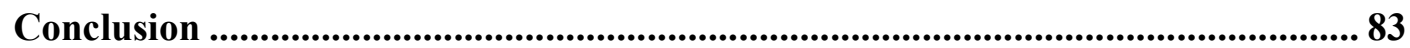

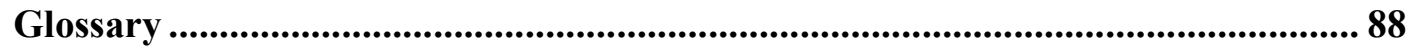

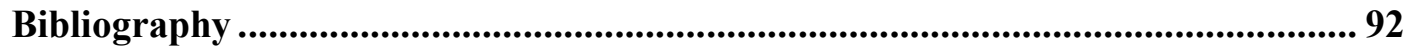




\section{Introduction}

This thesis is an examination of how the Russian radical right, in the age of globalization and information, constructs national identity in its body of written work. The extreme right in Russia is certainly not a monolithic political entity. Ideologies are inherently multi-faceted and sometimes paradoxical. This is a particularly relevant observation when one researches fringe politics. Compared to mainstream politics, fringe political ideologies exist on the peripheries of a community's main discursive stage. While mainstream politics work within a system of accepted political truisms and modes of conduct, such as accepting the legitimacy of the rule of law and the outcome of elections, fringe thinkers often work to overturn and replace those accepted norms. Thus, fringe ideologies on the outskirts of typical political discourse sometimes maintain that the only means of transforming society is through political extremism. This "low" form of peripheral politics is mirrored by a form of "high" peripheral politics. Like the "low" type, "high" peripheral politics maintains that the current system must fundamentally and drastically change. While sometimes participating in a cult of action and violence, thinkers and ideologues of "high" peripheral politics often maintain that the only way to affect true systemic change is to alter the dominant culture and worldview of society's elites. This Gramscian approach is the hallmark of the European Nouvelle Droite, or New Right which seeks to overthrow the dominant liberal culture of the modern West and replace it with an Identitarian, often racist, defense of Europe and European culture against what it perceives to be the civilization-killing effects of American culture. Similar but not identical to the ideologues of the Nouvelle Droite, such as Alain de Benoist and Tomislav Sunic is the Russian Eurasianst Alexander Dugin, whose body of ideas is the major subject of this work.

Alexander Dugin has recently risen in popularity as a notable thinker among the Russian right. He argues for a "radical centralism" that supports the leadership of Vladimir 
Putin and calls for the territorial expansion of the Russian Federation. ${ }^{1}$ He has admitted to being a follower of Julius Evola, who has himself been described by historians as a fascist apologist and reactionary. Furthermore, Dugin has openly accepted many of the major tenets of the European New Right such as the rejection of liberalism, egalitarianism, and multi-culturalism. Along with Dugin's calls for the formation of a greatly enlarged Russian, or Eurasian, empire, he has encouraged the formation of a new European empire, based on "Indo-European, Roman and Greek values."2 Over the years his activities and collective body of thought have drawn the interest of various scholars of fascism, neo-fascism and the broader New Right movement. Given his known political and philosophical affiliations it has become a recent trend among historians and political scientists to claim that, like many of his ideological allies, Dugin harbors racist sympathies or at least a sort of Russian supremacist worldview, despite his own arguments to the contrary.

The primary research question of this work, then, is how does Alexander Dugin conceive of nation and how does he define the Russian nation? Furthermore, is Dugin's Traditionalism and exhortation to preserve the cultural diversity of the world a façade created in order to cover up a fundamentally racist set of ideas? Additionally, how do his ideas differ from historical traditionalists like his personal inspiration, Julius Evola, as well as the broader intellectual currents present within the European and North American New Right?

The major argument of this study is that, contrary to some scholars who argue that Dugin is an ethnic Russian nationalist or even a racist, Dugin's avowed perennial Traditionalist worldview is genuine and it precludes his thinking from a completely ethnic understanding of nationalism. Rather, Dugin is a cultural and spiritual nationalist, one who maintains that nationhood is defined, not by race or ethnicity, but by the cultural and spiritual participation of

\footnotetext{
${ }^{1}$ Alexander Dugin, Putin vs Putin: Vladimir Putin Viewed From the Right (United Kingdom: Arktos, 2014$), 29$.

${ }^{2}$ Dugin, Putin vs Putin, 309.
} 
a people in their Traditional faith. Narrating the history of the world and the Russian nation through a fall-redemption myth-symbol complex, he ultimately defines Russians, and other peoples, as physical manifestations of sacred or spiritual ideas. For the Russians, their historic and spiritual destiny is that of a unifier and protector of other particular and smaller peoples. Nonetheless, despite much of his rhetoric of Neo-Eurasianism, the Russian nation is the most indispensable nation in Dugin's supranational project.

The Russian philosopher Alexander Dugin's Neo-Eurasianist movement, like the European New Right, seeks to create a fundamentally new identity in order to combat the United States and globalization. For the purposes of this project, I will be utilizing the concept of the "mythomoteur" created by Anthony D. Smith who is himself a determined promoter of the ethno-symbolist school when it comes to the question of what is a nation and how it is constituted. A mythomoteur, also known as a constitutive myth, is the major narrative taken up by a nation or nationalist project. Combined with a nation's myth-symbol complex it represents the chief means of deriving meaning for a nation and provides identity to individuals who are a part of that nation. These myths and symbols, passed down from a community's priests and storytellers over generations and even centuries, regardless of their foundation in reality, are the primary means by which national identities are constituted. Thus, a people must have a shared connection to a specific mythomoteur in order for a sense of shared nationhood to take root. Applying a fundamentally ethno-symbolic approach to Alexander Dugin's NeoEurasianist ideology, I hope to uncover the constitutive myths of the Eurasian mythomoteur promoted by Dugin.

In a literature review, I will explain in detail the major rifts and gaps within the current scholarship on Dugin and Neo-Eurasianism. In general there are two general interpretations among scholars as to Dugin's avowed Traditionalism and worldview. Some academics such as Marlene Laruelle connect Dugin's esoteric writings with the writings of noted Ariosophists 
such as Guido von List who portrayed Aryan man as a biologically supreme race. Other writers, like the theologian James Heiser, emphasize the eschatological nature of Dugin's writings which are in full agreement with Traditionalism. Still others, such as Andreas Umland maintain that despite his protestations, Dugin cannot be considered a Traditionalist as his ideas are largely aberrant from much of what can be considered Guénonian Traditionalism. I argue that Heiser's interpretation is closest to reality and that Dugin's Traditionalist writings are shorn of the biological racism of Julius Evola's thought while still maintaining Evola's religious and mystical worldview.

Given that this project is a multi-disciplinary endeavor I will be drawing from both social science and historical sources. In order to ascertain the nature of Dugin's sense of what does and does not constitute a nation, I will be drawing generally from the literature on theories of nationalism, but will examine neo-Eurasian nationalism primarily through an ethnosymbolic interpretive prism. Thus that part of the work will outline the broad currents of thought within the political science and history literature on nationalism.

In the Methodology section I will explain how I appraise Dugin's mythomoteur. This will be accomplished through exploring not only his own body of work, but also examining the work of Traditionalists such as René Guénon (1886 - 1951) and Julius Evola (1898 -1974), both of whom as Dugin notes have been particularly influential on his worldview. Thirdly, by examining contemporary racist thinkers in the New Right I hope to elucidate how Dugin has been seen as a problem to many racist New Rightists today, who have come to view Dugin as a multiculturalist subversive within right-wing politics. By examining all three broad bodies of literature I hope to explain how Dugin, while representing fundamentally violent and dangerous thought, nonetheless perceives the world very differently from real racists, contrary to what some scholars maintain.

The first chapter of the work provides general background information about Alexander 
Dugin, the early Eurasianists, who preceded and thus inform much of Dugin's thought, as well as the New Right. Here I will discuss the basic tenets of Dugin's Fourth Political Theory and his anti-modernism. Furthermore, I will discuss his geopolitical goals for the creation of a Eurasian empire.

The second chapter discusses the historic origins of the Eurasianist movement during the Russian Civil War. The early Eurasianists argued for a historiographical interpretation of Russian history as one that transcended East and West by idealizing Russia's historical connections to the Mongolian Empire. Then, the chapter will describe in brief the Cold War era origins of the European New Right and its expansion into North America.

Thirdly, I will discuss the historical origins of Traditionalism and the ideas of René Guénon and Julius Evola. It is impossible to understand Dugin's own worldview without understanding Traditionalism. Consequently, I will briefly discuss Julius Evola's interpretation of biological race and how it is conceivable that Alexander Dugin, given what he has written, has genuinely discounted race as meaningful in identity and has at most applied Evola's ideas of a sort of "spiritual race." As will be seen, Evola did not believe that race was a purely inherent biological trait. Rather, Evola conceived of race as a spiritual characteristic of individuals that could be elevated through station and virtuous living, regardless of ethnicity.

In the fourth chapter, this study will examine what Dugin has said on biological race and how he approaches identity. While outlining the seemingly racial components of his worldview and his desire for a violent confrontation with the United States, I will attempt to place Dugin into the context of a broader internal debate within the New Right, particularly among members of the North American New Right. This debate centers on how they should interpret Alexander Dugin's own body of thought. While there has been no consensus reached, racist thinkers such as Greg Johnson and Michael O’Meara have been adamant that Dugin is a subversive element within the New Right movement and his doctrine of multi-polarity and his 
anti-racism make him an enemy, not a friend, of White Nationalism and racist thought.

Ultimately, the novelty and uniqueness of this project derives from two major sources. By viewing Dugin's work through an ethno-symbolist interpretive prism we are able to understand that he conceives of nationhood in both an ethnic and spiritual sense. It is ethnic insofar as Russian stories, myths, and narratives form the essential myth-symbol complex of a larger, supranational project - Eurasianism. Yet Traditionalism colors his worldview and thus Russians are not just given substance by their shared myths and symbols, but by their messianic spiritual mission. Secondly, by discussing the recent debates within the New Right on Dugin, we bring to bear circumstantial, but no less important, evidence that Dugin's views, despite what some scholars might indicate, are fundamentally not racist. 


\section{Methodology and Sources}

This work was completed for an interdisciplinary purpose. Accordingly it relies on a broad collection of scholarship, both in history and social science. In order to articulate an argument on national identity, this study has drawn from a large pool of secondary references and analytical sources on the various theories of national identity formation and nationalism. Furthermore, in order to engage in the current scholarly debate over Alexander Dugin's fundamental worldview, I also draw on secondary sources that deal with Neo-Eurasianism and its intellectual and ideological ancestors.

This work is largely an examination of a thinker's body of thought, and in order to ascertain the major components of Neo-Eurasianisms myth-symbol complex, it is important to examine much of Alexander Dugin's writings in order to determine how he conceives of nation. Thus, in order to measure Alexander Dugin's proposed mythomoteur this work relies on primary sources including much of Dugin's own work. This comprises Dugin's attempts at theorizing what he calls the "Fourth Political Theory," his work on geopolitics as well as his more esoteric and mystical reflections. Other primary sources include the writings of Traditionalists and New Rightists in the aim of placing Dugin accurately within the context of extreme right-wing thought.

Concomitantly, Dugin's mythomoteur can be assessed indirectly through a careful understanding of the ideas espoused by the practitioners of Traditionalism such as Julius Evola. Therefore this study examines the ideas behind perennial Traditionalism and its connection with historical racist thought, particularly Ariosophy, sacred geography and the ideas behind National Socialism. This is done in order to engage in the debate concerning Dugin's conception of race as well as his deviation from Traditional thought outlining the racial, but ultimately spiritual, assessment of human beings in Evolian Traditionalism.

Thirdly, the mythomoteur of Alexander Dugin can be measured and assessed, if only 
circumstantially, through the criticism and reproaches aimed at him by members of the openly racist New Right or White Nationalists. Adherents of the New Right who have expressed openly racist ideas question Dugin's right to be among them. By examining their philosophical grievances with Dugin's claims on race this study can shed light on what truly shapes Dugin's worldview.

Based on the above mentioned research methods and materials, this study attempts to answer the following questions: How does Alexander Dugin appraise national identity? Who is a Russian and who is not? Does race or biology play a role in Dugin's conceptualization of national identity? How are Dugin's ideas and arguments received by the broader New Right community?

Ultimately, this work wishes to explain that Alexander Dugin professes a worldview that is profoundly anti-modern, anti-liberal and anti-American. Neo-Eurasianism is a dangerous ideology to world peace. Yet it is not a worldview that has a place for race or biology as a meaningful factor in the historical development of national identities, despite the accusations that scholars have levelled at Dugin's ideas in the past. 


\section{Literature Review}

Considering the massive body of literature produced by Dugin, scholars have attempted to synthesize his vision in order to fully understand just what his goals truly are. He has repeatedly and clearly stated that the United States' global hegemony must be defeated and that Russia must expand to include much of Eurasia and form an alliance with a pro-Russian Europe. Yet his eclectic intellectual background drawn from the European New Right, interwar esoteric religion, Russian Orthodoxy, and his own mystical Russian messianism has drawn scholars to question just which factors most influence Dugin's worldview, and, most importantly, through what framework does Dugin define the Russian nation. Most scholars accept that Dugin's worldview constitutes a Russo-centric totalitarian program that in the very least has been influenced by the German Conservative Revolutionary movement and a modicum of esoterica. However, a central point of debate dominates the discourse on Alexander Dugin and his philosophy. Specialists are divided on how to interpret Dugin's nationalisms. Some scholars emphasize Dugin's use of arcane themes such as sacred geography as a means of covertly espousing a racist or in the very least ethnic definition of identity. Conversely, other scholars maintain that Dugin's esoteric language is a manifestation of his fundamentalist religious worldview. 


\section{Dugin and Race}

One of the key debates centered on Dugin is how one can understand his approach to race. His ideas draw heavily on a fascistic cult of action and violence and his Russian expansionism coupled with conspiracy theories about a millennia-old war between the mercantile West and spiritual East has earned him the reputation among some scholars as a neo-fascist and covert anti-Semite. Marlene Laruelle admits that Dugin's worldview a mixed one and he has espoused often seemingly contradictory ideas. Nonetheless she contends that Dugin's worldview is in many ways colored by the concept of ethnicity and race. Laruelle argues that Dugin has been mainly influenced by the racist aspect of perennial Traditionalism through Julius Evola as well as the theory of ethnogenesis postulated by the revered Soviet scholar Lev Gumilev. She maintains that despite his rhetoric extolling the virtues of a multicultural world Dugin is nonetheless a fervent Russian nationalist who envisions a new Russian empire dominated by ethnic Russians. ${ }^{3}$

The first aspect of Dugin's racial identification of nation, according to Laruelle, is his links to Evolian Tradition and sacred geography. She emphasizes the strong correlation between the esoteric proto-and post-Nazi Ariosophy of Guido von List and Jorg von Liebensfels, and Dugin's own esoteric language. The esoteric racist doctrine of the Ariosophists claimed a racial homeland in the north called Atlantis, Thule, or Hyperborea. This ancient homeland was the birthplace of the racially superior Aryan people who brought culture and civilization to the world starting on the Indian subcontinent. Dugin, according to Laruelle, creates a similar narrative. In his 1991 book, The Mysteries of Eurasia, Dugin claims that "the continents have a symbolic significance." ${ }^{4}$ For Eurasia Dugin has discovered a northern homeland in Siberia - thus giving the Russians a Nordic identity, something that is essential in

\footnotetext{
${ }^{3}$ Marlene Laruelle, Russian Eurasianism: An Ideology of Empire, trans. Mischa Gabowitsch (Washington D.C.: Woodrow Wilson Press, 2012), 130.

${ }^{4}$ Quoted in Laruelle Russian Eurasianism, 130.
} 
a Nazi-inspired discourse. ${ }^{5}$ By utilizing esoteric language, Laruelle argues, Dugin merely covers what is in reality a highly racist worldview that sees Russians as a fundamentally Nordic, and superior, people.

Additionally, Laruelle highlights Dugin's intellectual debt to the works of Lev Gumilev, the celebrated Soviet ethnologist. ${ }^{6}$ Gumilev's theories, although very controversial in the West, remain a mainstay for many Russian scientists, who adhere to their pseudo-scientific examination of ethnicity. Gumilev posits a deterministic worldview that pits ethnicities against one another. Gumilev's conception of ethnicity is based largely on a "science of history" that maintains that history can be predicted. Furthermore, Gumilev argued that ethnicities were formed over centuries through peoples' interactions with the territory and soil that they inhabited. Ethnic mixing was strictly discouraged as the mixing of ethnicities would lead to the weakening of the biological stock of ethnic groups. ${ }^{7}$ Thus Laruelle maintains that despite Dugin's use of esoteric and religious language, he defines the Russian nation fundamentally along ethnic or even racist lines.

Similarly, Edith Clowes' book Russia on the Edge - Imagined Geographies and PostSoviet Identity is another example of scholarship that represents Dugin's Traditionalist rhetoric as largely ephemeral. ${ }^{8}$ Clowes notes that Dugin's flowery language of protecting national specificities is largely a cover for a greater Russian project that sees the fulfillment of Russian national interests as the only goal worth pursuing. By Clowes' reckoning, in any neo-Eurasian project the smaller nations inevitably will be swallowed up by its supposed protector, making Dugin's ideas nothing less than "political hypocrisy." Clowes, extends to religious hypocrisy. She condemns Dugin's supposed universalism when it

\footnotetext{
${ }^{5}$ Laruelle Russian Eurasianism, 130.

${ }^{6}$ Laruelle Russian Eurasianism, 116.

${ }^{7}$ Laruelle Russian Eurasianism, 69

${ }^{8}$ Edith Clowes, Russia on the Edge - Imagined Geographies and Post-Soviet Identity, (Ithaca and London: Cornell University Press, 2011), 44.

${ }^{9}$ Clowes, Russia on the Edge, 63.
} 
comes to generally favorable references to all world religions while simultaneously extolling the virtues of Russia for having Russian Orthodoxy as its official state religion.

Andreas Umland, who is a specialist on the post-communist Russian far right, has written extensively on the Neo-Eurasian phenomenon. In 2007 he maintained that Dugin's worldview was fundamentally Traditionalist arguing, "being framed by the ideas of Evola and other Traditionaists, Dugin sees Orthodoxy as only one of several religions that have preserved the initial "tradition." ${ }^{10}$ However, Umland has recently questioned his own argument that Dugin's worldview is fundamentally colored by his religious worldview. Now Andreas Umland along with Anton Shekhovtsov question the efficacy of calling Dugin a Traditionalist at all. In the article, "Is Alexander Dugin a Traditionalist? Neo-Eurasianism and Perennial Philosophy," Umland and Shekhovtsov counter Mark Sedgwick's argument ${ }^{11}$ that Dugin represents a recent, albeit innovative, manifestation of René Guénon's Traditionalist worldview. Umland and Shekhovtsov emphasize the influence of Evola rather than Guénon on Dugin's politics. According to this argument Guénon's Traditionalism was fundamentally based around changing one's own spiritual life in order to transcend modern decadence while Evola's was about changing society at large - often through violent means, thus neither Dugin or Evola represent Guénonian Tradition. ${ }^{12}$ Shorn of the label of Traditionalist and its accompanying universalism, Dugin's ideas appear increasingly secular and fascist.

\footnotetext{
${ }^{10}$ Andreas Umland, "Post-Soviet 'Uncivil Society' and the Rise of Alexandr Dugin - A Case Study in Extraparliamentary Radial Right in Contemporary Russia (Ph.D dissertation, Trinity College-Cambridge, 2007), 150.

${ }^{11}$ Mark Sedgwick, Against the Modern orld: Traditionalism and the Secret Intellectual History of the Twentieth Century, (Oxford: Oxford University Press, 2004), 225.

${ }^{12}$ Andreas Umland and Anton Shekhovtsov, "Is Alexander Dugin a Traditionalist? 'Neo-Eurasianism' and the Perennial Philosophy” The Russian Review 68 (October 2008), 676.
} 


\section{Dugin and Tradition}

Other scholars, however, hold that explaining Dugin's nationalism within an ethnic or racist paradigm makes little sense. In his discussion on nationalism in post-communist Russia, Wayne Allensworth argues that Dugin's religious approach bars Dugin from thinking of the Russian nation along ethnic or racial lines. Allensworth suggests that Dugin is attempting to create a new Russian mythomoteur. ${ }^{13}$ Appropriating the position of the Russian nation's chief storyteller, Dugin is creating a new narrative of Russian history and destiny that combines the Perennial Tradition with Russian messianism. He underlines the Russian nation's divine mission to unite other cultures around a protective Russian empire. Thus, Allensworth interprets Dugin's definition of nation along religious, albeit esoteric, lines.

The theologian, James Heiser, has produced a recent monograph that examines Dugin's eschatological thought. In "The American Empire Should Be Destroyed"” Aleksander Dugin and the Perils of Immanentized Eschatology" Heiser takes Dugin at his word that he is indeed a Traditionalist. Heiser likens Dugin's metaphysical outlook as something akin to political religion and maintains that the links between Dugin's Traditionalism and German racial theories are largely superficial. While Dugin makes use of the themes of an ancient prehistorical mythic landmass to the north that spawned a superior people, Heiser emphasizes that Dugin is largely talking about a spiritually superior people who held knowledge of the perenneial Tradition. Consequently, Heiser also maintains that Dugin's Neo-Eurasianism is not a racist ideology but fundamentally spiritual and religious.

The two debates discussed above represent the major points of conflict over how we

\footnotetext{
${ }^{13}$ Wayne Allensworth, "Dugin and the Eurasian Controversy: Is Eurasianism 'Patriotic?'” in Russian Nationalism and the National Reassertion of Russia, ed. Marlene Laruelle (London: Routledge, 2010), 116.
} 
are to interpret Dugin's philosophical worldview. The present work supports a position close to James Heiser's own understanding of Dugin. Fundamentally, Dugin envisions reality in genuinely religious and eschatological terms. Furthermore, it is accurate to describe Dugin as a Traditionalist. Despite Andreas Umland's contention that Julius Evola represented a major break from Traditionalism, this study maintains that regardless of Evola's difference in tactics from that of Guénon, they both shared fundamentally the exact same world view. For both Guénon and Evola the West was corrupt and dying, modernity and egalitarianism were great societal ills, and the West needed to return to Traditional forms of religious practice in order to save itself. Therefore, Dugin himself should be considered a Traditionalist.

This study also argues that Edith Clowes' interpretation of Dugin as a jingoist Russian nationalist, as well as Marlene Laruelle's argument that Dugin's worldview is heavily colored by Ariosophy and Julius Evola's racist worldview, are both not entirely correct. The present work will argue that despite his anti-liberalism and philosophical association with racial theorists, Dugin genuinely believes in what he says and that it is possible to participate in Evolian Traditionalism and not be a racist. Evola was indeed a racist. However, his racial theories were dominated by a belief in a "race of the spirit" as he saw biological racism as a symptom of decadent and modern scientific reductionism.

In addition to an attempt at contributing to the ongoing debate on Dugin, this work will utilize a source of material that many scholars have not utilized - the writings of the current New Right on Dugin. While it is certainly not a monolithic movement, the New Right has produced a bevy of literature that can help shed light on Dugin and how he views race. 


\section{Theoretical Framework}

\section{Theories of Nationalism}

The scholarly discussion concerning the study of nationalism and collective identities is a highly contested one. Indeed, the debate on defining exactly what constitutes a nation is one of the hallmarks of this thematic field. Nonetheless, many scholars agree on two fundamental points: A nation is neither a state nor an ethnic community. ${ }^{14}$ A nation can also be a state but usually a state relates to institutional activities whereas a nation is a community. A nation is a fundamentally lived experience whose members share the same homeland and national stories. Similarly, a nation cannot be an ethnic community because whereas a nation has a homeland or at least a sense of territory, an ethnic group does not have to be in possession of its historic territory. ${ }^{15}$ For the purposes of this thesis, I will use Anthony D. Smith's definition which says, "...The concept of nation is a named human community residing in a perceived homeland and having common myths and a shared history, a distinct public culture, and common laws and customs for all members." 16 Nationalism, then, is an ideology that strives to inculcate and protect the sense of identity of a mass of people that constitute the nation.

The scholarly debate over what is a nation and nationalism can be divided into two very broad camps: Primordialist and Modernist. Primordialists have insisted that nationality is fundamentally based in the deep past and that a nation is largely an extension of a real or imagined family or clan. However, the majority of scholars on nationalism today seem to largely emphasize the modern nature of national identities, pointing to the changes in technology and modes of production that have forced groups to re-evaluate their concept of

\footnotetext{
${ }^{14}$ Anthony D. Smith. Nationalism (Cambridge: Polity Press, 2010), 12.

${ }^{15}$ Smith. Nationalism, 12.

${ }^{16}$ Smith. Nationalism, 13.
} 
community.

The primordialist approach to the study of nationalism maintains that nationhood has been a facet of human nature since the Bronze age or even earlier. ${ }^{17}$ Built around expanding kin groups and shared histories and myths, according to primordialists, nations were in existence millennia before the French Revolution. They contend that recorded histories of ancient peoples and archaeological studies prove that nations and ethnic communities have long been part of the human experience and that "there is nothing particularly modern about nationalism, nor is it likely to disappear... ${ }^{18}$ "The Hebrews are cited as an example of nationhood being a pre-modern concept actively taken up by peoples. They did, after all, have a culture based around a unique religion, maintained a national homeland and had genealogical records. This sense of nationhood followed them even during the Diaspora as Hebrew remained the language of Judaism.

Primordialists also draw on the history of Ancient Greece and its community of the polis as an example of pre-modern national identity. The ancient Greeks, despite the many political and cultural differences between their many independent city-states, nonetheless espoused a sense of identity that went beyond the polis. The Greeks viewed those who did not share the general Hellenic culture as barbarians and often went on campaigns in defense of other Greeks; particularly against the Persian Empire. Spartans and Athenians, despite the chasm between their forms of government and cultures, nonetheless were able to unite together as a combined Hellenic force against invaders such as the Persians. Indeed, primordialists even see a sort of proto-irredentism in the Greek cities' attempts to reconquer Hellenic cities along the Ionian coast.

The contention that the nation has existed since essentially the beginning of time has

\footnotetext{
${ }^{17}$ Clifford Geertz, The Interpretation of Cultures: Selective Essays (New York: Basic Books, 1973), 259.

${ }^{18}$ Anthony D. Smith, The Ethnic Origins of Nations (New York: Basil Blackwell, 1986), 12.
} 
fostered a plethora of differing interpretations of the nation through time. One paradigm of the primordial nation can be described as ethno-biological primordialism. It postulates that nations can be traced back to racial or biologically-similar communities whose drives for reproduction were determined by a need to strengthen the gene pool. Thus a nation is essentially a large, biologically-defined kin group whose symbols and myths correspond to actual ethnic or biological origins. ${ }^{19}$ Another facet of primordialist thought emphasizes the shared "cultural givens," or cultural inheritance passed down from generation to generation, of nations. ${ }^{20}$ According to its leading proponent, Clifford Geertz, continued cultural givens such as ethnicity, local traditions and religion all constitute a real sense of nation. ${ }^{21}$ However, unlike some primordialists who believe in the reality of some nation's fixed social, cultural, and ethnic continuities throughout history, Geertz allows for the much more likely possibility that these continuities are just imagined. Geertz emphasizes a nation's need to believe in the primordiality of a people's ethnicity or nation. ${ }^{22}$ Thus, Geertz's primordialism allows for the notion of a constructed past that is in fact outside of reality.

Another strain of primordialist thought is one championed by spiritual nationalists who have been highly influenced by European Romanticism as well as their own professed faith. This method of explaining nationhood and national identity is largely focused on explaining a nation or ethnicity's divinely-inspired plan. If the nation existed during the first human civilizations, and humans were divinely created, then the nation itself is a part of the divine plan. In early history, this sort of spiritual nationalism may be attributed to the ancient Hebrews and their belief that they were a "chosen people." More recently and closer to the modern, secular era many European powers and the United States utilized a narrative that was similar; maintaining that it was their God-given duty to bring civilization and Christianity to East Asia

\footnotetext{
${ }^{19}$ Smith, Nationalism, 56.

${ }^{20}$ Geertz, The Interpretation of Cultures: Selective Essays, 260.

${ }^{21}$ Clifford Geertz, The Integrative Revolution (London: Fontana, 1973), 259.

${ }^{22}$ Geertz, The Integrative Revolution, 259.
} 
and Africa. This culture-bearing civilizing mission became a defining trait of many early Russian thinkers' sense of national identity, which maintained that the Russian people, representing the Orthodox Christian traits of simplicity, rootedness, and communalism must champion and spread true Christian values to Central Asia as opposed to the materialistic values of the Latin West. Other thinkers, such as Johann Gottfried von Herder, maintained a less evangelical concept of the nation. He held that each nation, defined as it was by language and a divine idea, must be given the freedom to express itself. In all cases of spiritual nationalism, the nation is defined by its divinely-given mission.

A very similar school of thought to the primordialist position is that of perennialsm. Like the primordialists, perennialists argue that nations have existed centuries or even millennia prior to the advent of modernity. However, they fully accept that nationalism is a purely modern phenomenon. ${ }^{23}$ Contrary to primordialism, perennialists such as Joshua Fishman argue that nations are strictly social and historical phenomena and do not occur naturally. ${ }^{24}$ The historical nation, then, is a shared experience through community, not necessarily through kinship.. Perennialism comes in two main forms. The first, continuous perennialism, essentially posits that many nations have persistently existed throughout time as the same shared cultural experience for centuries prior to modernity such as the French, English and Russians. ${ }^{25}$ The second strain of perennialist thought is recurrent perennialism: this school of thought argues that various nations can come into existence and disappear over time but the idea of a national community has existed essentially since the first formations of human societies. ${ }^{26}$

The second and most widely-accepted major explanation of how the nation and

\footnotetext{
${ }^{23}$ Anthony D. Smith, Nationalism and Modernism: A Critical Survey of Recent Theories of Nations and Nationalism (London and New York: Routledge, 1998) 159.

${ }^{24}$ Joshua Fishman, ed. P. Sugar "Social Theory and Ethnography: Neglected Perspectives on Language and Ethnicity in Eastern Europe," Ethnic Diversity and Conflict in Eastern Europe (Santa Barbara: ABC-Clio, 1980), 71.

${ }^{25}$ Smith, Nationalism, 54.

${ }^{26}$ Smith, Nationalism, 54-55.
} 
nationalism developed is advanced by the modernist school. The modernist theory of nationalism is represented by many scholars such as Eric Hobsbawm and Benedict Anderson who emphasize different aspects of the constructed nature of the nation. Some scholars emphasize the deliberate decision of economic and political elites to foster a new, ethnolinguistic national identity that transcended previous local and class identities in order to maximize economic profit and facilitate easier administration of increasingly centralized states. The nation must have been not only a modern idea, but also a modern reality because prior to modern societies, there had been no need or means of conceiving the idea of a national community.

Prior to industrialization and the advent of modern capitalism, society was feudal. In these feudal societies, the major economic preoccupation was agriculture. A gradual shift from a feudal economy and social order to an industrialized, urban and centralizing society and state was legitimized intellectually initially by Renaissance Humanism and later developed during the Enlightenment. ${ }^{27}$ The human ability to understand complicated but rational systems in nature led to a belief that humans could also create a rational and efficiently run society. Consequently, standardization of social interaction became increasingly important. Speakers of local languages and dialects, once left to their own devices in largely isolated communities of the feudal era, were put under pressure to conform to a new, standardized language that was largely a reflection of the dialect of the national capital, such as Parisian French. With a universally accepted linguistic standard, workers could be more easily trained on how to perform their duties and bureaucrats could more effectively run government and local affairs. Ultimately local identities were subsumed by a broader national one in the name of administrative efficiency and economic profit.

\footnotetext{
${ }^{27}$ Wayne Allensworth, The Russian Question: Nationalism, Modernization and Post-Communist Russia. (Lanham: Rowman \& Littlefield Publishers, 1998), 5.
} 
While the above explanation of the emergence of the modern nation emphasizes economic factors, other scholars maintain that nationalism was born out of cultural necessity. Pointing to the growing educated and cosmopolitan elite, Ernest Gellner maintains that national consciousness was born naturally out of the emergence of unifying national languages and culture. ${ }^{28}$ In Gellner's approach, national identity and industrialism partake in a symbiotic relationship. Industrialization and the necessity for linguistic and technical standardization foster a sense of national identity which in turn nurtures industrialization. Conversely, some modernist scholars hold that the nation is an inherently ideological construct. Rather than having been created by the needs of political and economic elites, nations and nation-building were a direct result of the Enlightenment and nationalist ideologies. Born out of Kantian ideas of self-determination combined with an increasingly literate populace, nationalism was a natural outgrowth of many contemporary intellectuals' drive to create homogenous nations. Thus, in this ideological model, intellectuals, not political elites, have agency and are the primary bearers of nationalism. ${ }^{29}$

Other modernists, however, emphasize the purely constructed nature of nationalism. In his seminal work, Imagined Communities, Benedict Anderson contends that a nation is a socially constructed entity, imagined by individuals who perceive themselves as part of that entity. The advent of print capitalism, and the entrepreneurial mass distribution of printed works in the vernacular, allowed the literate to mentally envision a larger community who shared their language. With a broader understanding of their linguistic community, peoples formed a concept of their nation as inherently finite yet sovereign. Its borders were fixed and the people, those who shared in the vernacular language and culture, embraced this new sense of national identity. ${ }^{30}$ Additionally, improved infrastructure enabled formerly relatively isolated

\footnotetext{
${ }^{28}$ Ernest Gellner. Thought And Change (London: Weidenfeld and Nicolson, 1964) ch. 7.

${ }^{29}$ Smith, Nationalism, 52.

${ }^{30}$ Benedict Anderson, Imagined Communities: Reflections on the Origins and Spread of Nationalism, (London: Verso, 1991), 7.
} 
communities to imagine a world outside of their own immediate village or town. Yet, Anderson emphasizes, the nation envisioned is a psychologically constructed one. The lack of face-toface interaction with the entirety of the nation necessitates the use of an individual's imagination to form a national community.

Like Anderson, Eric Hobsbawm contends that the nation and nationalism are both necessarily products of modernity. However, Hobsbawm introduces a Marxist approach to the historiography of the nation and emphasizes the agency of elites in the nation-building process. Hobsbawm is a critic of the national project, and emphasizes that political and economic elites have essentially fostered a false sense of national consciousness among large social groups in order to better control them. Nations and nationalism were largely forged in Europe from around 1830-1870 according to Hobsbawm. During these years a wealth of historical and literary works helped create a sense of collective identity among the masses. A bevy of "invented traditions" followed suit; the creation of national flags, music, songs, histories, festivals and ceremonies of national mourning and celebration were means by which the ruling elites forged national identity. ${ }^{31}$ Made to appear as if the traditions were centuries old and thus providing their practice with some legitimacy, they were simply recent innovations. Accordingly, Hobsbawm views nations as essentially social constructs, created by modern elites as a means of fostering a false sense of identity crafted by social engineers as a means of controlling people through their emotional attachment to an abstraction. ${ }^{32}$

Recent scholarship by Rogers Brubaker has brought about a new way of engaging in the ideas of race, ethnicity and nation. Brubaker argues that scholars should look at nationhood and identity not as an actuality but as a cognitive process. ${ }^{33}$ In other words, national identities

\footnotetext{
${ }^{31}$ Eric Hobsbawm and Terrence Ranger, The Invention of Tradition (Cambridge: Cambridge University Press, 1983), 13.

${ }^{32}$ Hobsbawm and Ranger, 14.

${ }^{33}$ Rogers Brubaker, Ethnicity Without Groups (Cambridge: Harvard University Press, 2004), 17.
} 


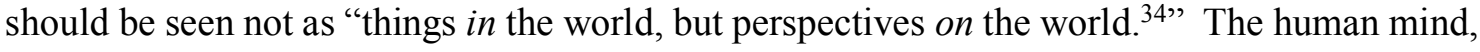
he argues, naturally creates categories such as ethnicity and national identity as a means of making sense of our world. Thus, instead of trying to define what a nation really is, scholars are better off asking why humans have for so long seen things through an ethnic lens.

While the modernist approach dominates the field of nationalism studies, there is a third broad current of thought that acts as a sort of mediating theory between modernism and primordialism. This third paradigm of ethno-symbolism, which seeks to explain nations and nationalism, is one that emphasizes the continuities of ethnic communities throughout history while still not engaging in a primordialist account of history. The nation is not something that is invented, but rather the nation is something that has been reinterpreted. Contrary to the modernist approach, ethno-symbolists maintain that nation is not a purely elite-dominated construction, nor is it necessarily modern. Rather, they emphasize that throughout history interplay between elites and the middle- and lower-strata of society have together created a sense of national community. Anthony D. Smith uses the nineteenth-century Gaelic revival in Ireland as an example of the reciprocal nature of the elite and non-elite participation in a common identity-forming project. ${ }^{35}$ By the late nineteenth-century the Irish language was becoming more and more of a provincial language as English increasingly became the main language of public discourse. A Gaelic League was established by lower-class Irishmen in order to protect and encourage the use of Irish as the main language of the island. Utilizing traditional Catholic and Irish-language symbols in their drive for the reinstitution of the Irish language, these same symbols were later taken up by members of the Irish intellectuals. ${ }^{36}$ Besides the emphasis placed on the reciprocal identity-forming relations of elites and non-elites, ethno-symbolists maintain that any account of nation-forming must take into

\footnotetext{
${ }^{34}$ Brubaker, Ethnicity Without Groups, 17.

${ }^{35}$ Smith, Nationalism, 61.

${ }^{36}$ Smith, Nationalism, 61.
} 
account the longue durée. ${ }^{37}$ Influenced by the Annales School of historiography, the political scientist John A. Armstrong maintains that only through examining a historical subject in the long term can specialists avoid applying anachronistic labels to historical subjects. Armstrong created the concept of the myth-symbol complex; a collection of stories and symbols specific to the ethnic core of a nation that have been gathered, recast, and retold through the generations. ${ }^{38}$ Consequently, to understand the phenomenon of a specific nation and nationalism, it is imperative that one examines it over the process of generations and even centuries.

Subsequently, the ethno-symbolic approach stresses the importance of locating the modern nation within the long-term time span of previous ethnic communities. Smith maintains that this is not an easy task; the link between an ethnic community and its later manifestation as a nation is tenuous and hard to track. On the other hand, nations can be seen as competing with other ethnic groups such as the Flemish and Walloons within Belgium or Basques and Catalans within Spain. ${ }^{39}$ Thus nations and ethnic groups, what Smith calls ethnies can be seen as a part of a broader cultural family of communities. This ethno-cultural community might be able to explain why national groups in the present utilize myths and symbols of earlier ethnic communities that may not actually have been ancestors - such as early Russian Eurasianism's cult of the Mongolian nomad.

A fourth facet of the ethno-symbolist approach is how it explains the sometimes deep attachments fostered by nationalism. These attachments can sometimes lead to political extremism, terrorism, and a belief in the superiority or the messianic mission of a nation. While primordialists can either emphasize an ethno-biological or a spiritual or largely culturallinguistic definition of nation, and a modernist its recent emergence, the ethno-symbolist

\footnotetext{
${ }^{37}$ Anthony D. Smith, Nationalism and Modernism, (London and New York: Routledge, 1998), 170.

${ }^{38}$ Ozkirimli, Umut Theories of Nationalism: A critical Introduction, (New York: Palgrave Macmillan, 2010), 145.

${ }^{39}$ Smith, Nationalism, 62.
} 
highlights the nation's historical ethnic core. This ethnic core, real or imagined, constitutes a powerful symbol to the individual member of his nation. A mixture of a feeling of ethnic belonging combined with shared symbols, myths, and histories create a strong sense of belonging. Therefore, the ethno-symbolist maintains, it is not likely that ultranationalism and nationalist violence will go away any time soon.

Ultimately, the ethno-symbolist approach posits that a nation is defined by its mythsymbol complex which has been passed down from generation to generation through an ethnic group's storytellers. This collection of collectively recognized symbols and myths, along with its main narrative myth, what Smith calls the "mythomoteur," gives a nation its sense of meaning. Smith recognizes three major types of mythomoteur: the communal-political, the communal-religious, and the dynastic. In order for the modern nation to be constructed, it must have already had a common ethnic core along with a myth-symbol complex that resonates psychologically enough with the different provinces and localities a nationalist project wishes to integrate. If it does not, it must re-invent one or risk collapsing. Thus the only successful nations, the ones who have been able to successfully integrate somewhat different territories into a collective national collectivity, are those that have a sufficiently appealing mythomoteur. ${ }^{40}$

Wayne Allensworth follows this logic by using the French nation as an example. ${ }^{41} \mathrm{He}$ maintains that it was much easier to make Frenchmen out of Bretons and Gascoqne, compared to Algerian Arabs, even though both groups speak French and Algeria had at one time been a part of France. This is because Bretons and Gascoqne share a closer tie to the French mythsymbol complex than Algerian Arabs do. While Gascoqne and Bretons might have their own particular local traditions and histories, they nonetheless share a myth-symbol complex that

\footnotetext{
${ }^{40}$ Smith, Ethnic Origins of Nationalism, 255.

${ }^{41}$ Allensworth, 8.
} 
includes Catholicism, the history of the Hundred Years war and memory of the French monarchy. On the other hand, despite the history between Algeria and France, Algerian Arabs have a much different myth-symbol complex that includes the Islamic faith and its symbols, as well as a completely different ethnic background. Additionally Algerians utilize a different mythomoteur that includes anti-imperialism due in part to the violent relationship between France and its Algerian colony. ${ }^{42}$ An example of a constructed yet successful modern mythomoteur would be that of the nation of Israel. Although the Hebrews had been away from their ancient homeland for centuries and had been separated throughout a diaspora, the formation of an Israeli national idea was largely successful. Despite the linguistic and ethnic differences between many Jews repatriated to Israel in the latter half of the twentieth century, Israel nonetheless produced a salient mythomoteur that included key parts of ancient Hebrew and modern Jewish history such as the Exodus, King David, and the Holocaust, all of which became part of Israel's constitutive national myth.

Smith notes that most constitutive myths of ethnic origins follow a similar format. The blueprint includes the following:

1. a myth of origins in time; i.e. when the community was 'born';

2. a myth of origins in space; i.e. where the community was 'born';

3. a myth of ancestry; i.e. who bore us, and how we are descended from him/her;

4. a myth of migration; i.e. whither we wandered;

5. a myth of liberation; i.e. how we were freed;

6. a myth of the golden age; i.e. how we became great and heroic;

7. a myth of decline; i.e. how we decayed and were conquered/exiled;

8. a myth of rebirth; i.e. how we shall be restored to our former glory. ${ }^{43}$

\footnotetext{
${ }^{42}$ Allensworth, 8.

${ }^{43}$ Smith, Ethnic Origins of Nations, 256.
} 
According to Smith, a large ethnic group that wishes to absorb other, smaller ones in order to create a nation must draw on enough of the mythic elements of the narrative blueprint listed above and must share enough commonalities with the lesser groups to be a foundation for a shared national identity. Thus the ethno-symbolist approach is in some ways a happy medium between the other two broad currents of thought on nationalism and national identity. Its emphasis on the primacy of an ethnic core and a constitutive national mythology of a nation's origins and its past history is a means of accepting the often pre-modern nature of nations. At the same time, ethno-symbolism represents a compromise with modernism by allowing that while a nation's essence, real or imagined, is inherently pre-modern in its myth structure, the nation itself usually requires the construction of a myth-symbol complex in order to incorporate smaller yet similar groups into the nation. Thus the making of a nation remains in some ways a social construct.

Neo-Eurasianism cannot be explained through a primordialist conception of Russian nationhood or a greater supranational project such as the construction of a Eurasian identity. Primordialism presupposes the existence of a national identity prior to the advent of modernity and this is clearly not the case with Dugin's Neo-Eurasianism which has a decidedly constructivist aspect. At the same time, the modernist approach to national identity cannot adequately explain Dugin's approach to and utilization of myths and symbols, drawn from both Traditionalism and historical Russian messianism.

Thus, in order to better understand Dugin's Neo-Eurasianist project, and the role that the Russian nation will play in it, it is important to utilize a conception of nationalism that can be applied to a multi-faceted body of thought such as Dugin's. The ethno-symbolic approach to national identity studies is a useful prism through which to examine Alexander Dugin's conceptualization of national identity. This is in part because ethno-symbolism is an excellent 
"compromise" between the primordialist and modernist camps because it acknowledges the possibility that national identity can be formed from a combination of pre-modern as well as modern, constructivist, influences. Thus, utilizing the idea of a myth-symbol complex we are able to see how Dugin constructs identity through a combination of Traditional and esoteric stories to explain the meaning and ultimately the destiny of Russia. 


\section{Chapter 1: Alexander Dugin: His Political Life and Ideas}

His ideology is not grounded upon racial or ethnic notions of identity, despite his fascistic leanings. Nor does he participate in the Early Eurasianist belief in the fundamental Asian character of Russians. Rather, Dugin's ideology is grounded in the esoteric belief in a Perennial Tradition of which Orthodox Christianity and other Eurasian traditional religions represent facets of a single divine truth. Combining a myth-symbol complex utilizing a mixture of Traditionalist belief in Russia's messianic need to unify and protect other peoples of eastern Orthodox faith and a reverence for Russia's simpler past, Dugin has created a mythomoteur that constitutes a new identity for the Russian national; that of the divinely-inspired unifying force to bring Russia and the rest of the world not to Orthodoxy, but to the Perennial Tradition.

Dugin has participated in Russian politics in one capacity or another since before the end of Boris Yeltsin's presidency. In 1998 Dugin participated in the Pamyat organization, hoping to bring to it his more esoteric explanation of Russian history. However, Pamyat's reactionary monarchism and unbridled anti-Semitism reportedly drove Dugin away. After the split, Dugin founded several institutions such as the publishing house Arctogaia Association and became an unofficial advisor to Gennady Zyuganov, the head of the Communist Party of the Russian Federation (CPRF). Next Dugin attempted to form his own political party. Working with Eduard Limonov he formed the National Bolshevik Party (NBP) which utilized a radical synthesis of both Stalinist and National Socialist symbolism and rhetoric. ${ }^{44}$ Directly inspiring Zhirinovsky's 1994 autobiography The Last Drive to the South, Dugin has called for a new Russian empire to expand into the former Soviet Union, northern China, Central Asia and also

\footnotetext{
${ }^{44}$ Anton Barbashin and Hannah Thoburn, "Putin's Brain: Alexander Dugin and the Philosophy Behind Putin's Invasion of Crimea," Foreign Affairs, March 31, $2014<$ http://www.foreignaffairs.com/articles/141080/antonbarbashin-and-hannah-thoburn/putins-brain>.
} 
Eastern Europe. Dugin has a presence in Russian academia as a professor of sociology at Moscow State University and is the Director of the Center for Conservative Studies at MSU. Furthermore Dugin is a television personality, having participated in political discussions on Russian as well as foreign programs, including one broadcast from Iran. A prolific writer, he has served as advisor to the State Duma and his Foundations of Geopolitics has been on the required reading lists of Russian military officer schools. His work has been rumored to have had the ear of Putin himself from time to time. ${ }^{45}$

In his 2001 manifesto of the Eurasianist Movement, Dugin decried a fallen world in which totalitarian uniformity and consumerism are the only hallmarks of the modern life. ${ }^{46}$ Additionally angered by the seeming political and ideological apathy of the masses, he wrote, "The majority of political parties and formalized social movements pursue tactical purposes. Practically nowhere can be found an explicit and consequent ideology capable to snatch man from a state of sleepy indifference, to make life worth living." ${ }^{47}$ For Dugin, this philosophical ennui has been largely fostered by the victory of American liberal democracy and Americanization of the cultures of the world, which he describes as an "Atlanticist tsunami."48 In addition to what he sees as the death of ideology, Dugin also mourns the dissolution of the Soviet Union, which he regards an unmitigated disaster. According to Dugin, the end of the Soviet Union meant the effective end of organized opposition to globalization and Americanization. However, rather than a restoration of the Soviet Union Dugin proposes a new political union, a Eurasian one. A Eurasianist empire would stretch into territories and countries that neither the Russian Empire nor the Soviet Union had ever ruled over. The Eurasianist

\footnotetext{
${ }^{45}$ Barbashin and Thoburn, "Putin's Brain."

${ }^{46}$ Alexander Dugin, Eurasia Above All: Manifest of the Eurasist Movement,

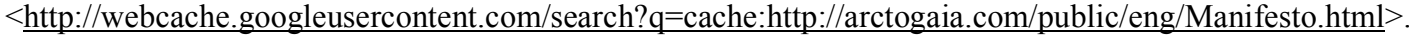

${ }^{47}$ Alexander Dugin, Eurasia Above All: Manifest of the Eurasist Movement, $<$ http://webcache.googleusercontent.com/search?q=cache:http://arctogaia.com/public/eng/Manifesto.html $>$.

${ }^{48}$ Alexander Dugin, Eurasia Above All: Manifest of the Eurasist Movement, $<$ http://webcache.googleusercontent.com/search?q=cache:http://arctogaia.com/public/eng/Manifesto.html $>$.
} 
movement represents a supranational project that will unite many different religions and ethnic groups into a single empire. On the surface, Dugin's geopolitical vision appears to be driven by a desire for the maximization of Russian power and influence. To some extent, that is correct. However, pregnant within Dugin's territorial ambitions for a Eurasianist empire are Traditional ideas of sacred space as well as a new ideological model of identity. The model incorporates ideas of both civilization and the spiritual missions of peoples as constitutive facets of identity. The Eurasianist project ultimately posits a new mythomoteur for Russians by portraying Russia as an important "glue" to a greater Eurasian empire, thus fulfilling its divinely-ordained mission - to be a uniter of peoples.

In Dugin's popular work, The Fourth Political Theory, he proposes that in order to counter the deculturating effects of modernity and globalization, a new ideology must be created. He argues that the modern world has seen the advent of three major ideologies; liberalism, communism, and fascism. ${ }^{49}$ Of the three, only liberalism has survived the wars that the competing systems had spawned. He then posits that of the three major ideologies, each one had a primary agent that effectively "moved" history and that all three believed in monolinear time that was deterministic and utopian. ${ }^{50}$ In the case of liberalism, the major historical actor was the individual. Dugins's views on liberalism are similar to those proposed by the Nouvelle Droite. The history of the individual was one of progress and liberation in which the individual is "liberated from all things external to oneself." 51 This leads to the individual's renunciation of his God and spiritual upbringing, then his community, his family, and even his gender. In the ideology of liberalism, Dugin fears, lies self-destruction. In the same vein, communism also espoused a belief in the inevitable progress of man. However, communism's major historical subject was not the individual but class. According to communist discourse

\footnotetext{
${ }^{49}$ Alexander Dugin, The Fourth Political Theory, (London: Arktos, 2012), 55.

${ }^{50}$ Dugin, The Fourth Political Theory, 55.

${ }^{51}$ Dugin, The Fourth Political Theory, 37.
} 
class conflict determined human history and it was a scientific reality that eventually a worldwide proletarian revolution would occur and create a utopian, classless society. However, Dugin views communism as a horrible alternative to liberalism because it shares its materialism, scientific determinism, and atheistic spirit. ${ }^{52}$ The third ideology, fascism, exemplified by the statism of Fascist Italy and the unfettered biological racism of National Socialism, apparently disgusts Dugin. Dugin rails against racism and the "criminal practice of wiping out entire ethnic groups..." and blames it as the sole cause of the Second World War. ${ }^{53}$ Simultaneously he decries the guilt by association experienced by Conservative Revolutionaries and the vilification of their ideas as a form of "racism." ${ }^{54}$ Indeed, liberalism, concomitant with a culture of political correctness and an incontrovertible faith in its universalizing mission, represents another form of "racism" for Dugin.

According to Dugin's Fourth Political Theory, he rejects both communism and fascism as inadequate models to combat what he sees as the sinister destructiveness of liberalism. Instead, Dugin proposes a new historical "subject:" civilization. Advancing the concept of civilization as a historical actor in the modern world, Dugin has effectively created a vehicle and intellectual justification for his Eurasianist project. Admitting that the definition of civilization is highly contested, he posits a challenge to Samuel P. Huntington's register of civilizations. In his influential work The Clash of Civilizations, Huntington argued that there was a Western civilization embodying North America, Canada, Australia and much of Europe, as well as Latin American, African, Islamic, Japanese, Sinic, Hindu, Buddhist and Orthodox civilizations. ${ }^{55}$ Dugin asserts that Canada and the United States, along with the United Kingdom, are not part of Western civilization but rather an Atlanticist current within Western

\footnotetext{
52 Dugin, The Fourth Political Theory, 38.

${ }^{53}$ Dugin, The Fourth Political Theory, 44.

${ }^{54}$ Dugin, The Fourth Political Theory, 44.

${ }^{55}$ Samuel P. Huntington, Clash of Civilizations and the Remaking of World Order (New York: Simon and Schuster, 1996), 21.
} 
civilization along with the United Kingdom. ${ }^{56}$ Indeed, Europe is divided between a fundamentally Atlanticist and Continental Europe, the latter wishing closer ties with Russia as well as the loosening of ties with the United States and globalization in general. Similarly, Dugin rejects Huntington's appraisal of Orthodox civilization, containing much of the Balkans and the former Soviet Union. Rather, Dugin maintains that Orthodox civilization should be understood as a part of a greater Eurasian civilization, including Mongols, Turks, Caucasians, and "a significant proportion of the population professing Islam," all with shared histories with Russia. ${ }^{57}$ In his attempt at devising a political theory to be used to counter globalization, Dugin argues for a civilizational model that sees a much strengthened Russia.

One of the most important works written by Alexander Dugin is Osnovi Geopolitiki, or The Foundations of Geopolitics. It is a work that articulates in detail Dugin's territorial basis for the dismantlement of what he sees as American global domination and the rise of a great Eurasian empire united by the Russian nation. In order to bring down American global hegemony Dugin proposes a massive alliance that will utilize the resources and manpower of Asia and Europe. Simultaneously, Dugin calls for the support of any American separatist movements, including "Afro-American racists," in order to destabilize and weaken the United States. ${ }^{58}$ Additionally, Dugin maintains that only an extreme redrawing of the world map will ensure the fulfillment of Russia's spiritual mission and a return to a multi-polar world.

Dugin proposes the formation of several alliance systems between Russia and other partners to ensure the success of the Eurasianist project. Firstly, a Moscow-Berlin axis should be formed. To realize it, Russia would return East Prussia back to Germany which, along with France, would also dominate much of Scandinavia and central and southern Europe. ${ }^{59}$ In addition, a similar Moscow-Tokyo alliance, along with India and Vietnam, will ensure the

\footnotetext{
${ }^{56}$ Dugin, The Fourth Political Theory, 118.

${ }^{57}$ Dugin, The Fourth Political Theory, 118.

${ }^{58}$ Dugin, The Fourth Political Theory, 118.

${ }^{59}$ Alexander Dugin, Osnovi Geopolitiki, <http://www.my.arcto.ru/public/osnovygeo/>, Ch. 4.
} 
dismemberment of China's borderlands, as Dugin considers China to be an enemy to any Eurasianist mission. In compensation, China would receive de facto hegemony over Southeast Asia excluding Vietnam as well as the Philippines, Indonesia, and Australia. Japan would receive the Kurile Islands back from Russia and be allowed to pursue an imperial policy not unlike that of Imperial Japan during the Second World War. ${ }^{60}$ The Pacific islands, and presumably Hawaii too, would fall under Japanese control. The final major alliance proposed by Dugin is one with Islamic Iran which he considers a natural ally of Russia against American cultural imperialism and thus willing to provide naval bases for the Russian navy, allowing it access to the Indian Ocean. ${ }^{61}$ Turkey would also be severely weakened with the secession of a Kurdish state but ultimately gain its own hegemony over much of the Arabian Peninsula, Jordan, Iraq, and Syria. Ultimately, the borders of a Eurasian-Russian empire would include not only almost all of the former Soviet Union, but also Mongolia, Tibet, Sinkiang, almost all of the Caucusus, Finland, Poland, and almost all of the Balkans. ${ }^{62}$

Russian imperialists have historically utilized a missionary and evangelical message to justify expansionism. During the eighteenth and nineteenth centuries, the Russian Empire often maintained that the spread of Russian influence throughout Central and East Asia was necessary to bring the light of Orthodoxy and the just rule of the Tsars to the native peoples. When dealing with the Balkan Slavs or the Ottoman Empire the official narrative espoused by Russian authorities was that Russia needed to protect Slavic and Orthodox minorities from the persecutions of non-Orthodox rulers. Similarly, the creation of the Soviet Union led to a change in the justificatory language of Russian expansion, but not its fundamental mission to expand state power. After the fall of the Soviet Union, Putin's Russia has argued for the protection of ethnic Russians in the "near-abroad." In the name of protecting ethnic Russians, the Russian

\footnotetext{
${ }^{60}$ Dugin, Osnovi Geopolitiki, <http://www.my.arcto.ru/public/osnovygeo/>, Ch. 4.

${ }^{61}$ Dugin, Osnovi Geopolitiki, Ch. 4.

62 Dugin, Osnovi Geopolitiki, Ch. 4.
} 
Federation has violently attempted to dismember its neighbors as can be seen in the 2008 war with Georgia and the more recent annexation of Crimea and the support of pro-Russian separatists in eastern Ukraine. However, the dissolution of the Soviet Union and the constriction of Russia's borders have meant that pursuing an ethnic justification of expansion is problematic for greater imperial goals. This is because most of the ethnic Russians requiring "protection" are along the borders of Russia and within former Soviet Union republics. Thus, any plans to successfully extend Russia's current borders into former Soviet republics would more than likely require force and a convincing ideological motive. Alexander Dugin's NeoEurasianism represents a potentially very useful ideological tool to articulate what he sees as a necessary expansion of Russian territory.

Yet Dugin's philosophical and geopolitical worldview was not created in a vacuum. Indeed, his conception of a Russia that transcends both East and West and is, in fact, a unifier of peoples is nothing new. Ideas attributing a specifically Eurasian character to Russia can be traced back to the work of a small group of Russian dissident intellectuals who went into selfexile in Europe during the Russian Civil War. During the 1920s they formulated a philosophy of Eurasianism that contained the geopolitical goals and idealization of Russia's history that is present in Dugin's philosophy today. Similarly, Dugin is not alone in his post-war antiliberalism and anti-modernism.

Indeed, Dugin's anti-democratic conclusions harken back to the French Nouvelle Droite of the Cold War era. This intellectual movement aims at dismantling what they see as American hegemony over Europe and has had a profound influence on Dugin's own thinking and the Neo-Eurasian mythomoteur. In order to understand the nature of Dugin's Neo-Eurasianist doctrine it is imperative to place his ideas in a historical context. Employing the ethnosymbolist approach to nationhood and the concept of the mythomoteur, I will trace the ideological lineage of Dugin's Neo-Eurasianism back to the early Eurasianists of the interwar 
period, Lev Gumilev's ethnic theories as well as the ideas espoused by members of the Nouvelle Droite. 


\section{Chapter 2: Early Eurasianism, Lev Gumilev and the French Nouvelle Droite}

During the Russian Civil War a plethora of constitutive myths flourished not only in Russia proper but also in the Russian émigré community. Indeed the Civil War was in many ways a war between competing mythomoters. For the Bolsheviks, the meaning of Russia was defined by its war against international capitalism. With the creation of the Soviet Union in 1922 Russia became a nominally equal partner in a union of politically like-minded but linguistically and culturally diverse republics. Generally speaking, prior to Stalin the chief paradigm through which communist discourse was viewed was always that of class. According to the communist narrative, to be Russian was to be part of a larger international proletarian revolution. On the other hand the White movement was deeply divided. Monarchists who fought against the Bolsheviks championed a pre-revolutionary adoration for Tsar and Church. Their Russia was a Russia very similar to the Russia that existed before the First World War. Others wanted a liberalized and democratized Russia and largely viewed Russia as a part of Europe, thus connecting their "imagined nation" to the Enlightenment and Western liberal apostles of free market capitalism. Still others created a completely new approach to Russian history and nationhood.

The Eurasianists were a relatively small and diverse group of Russian émigrés who initially fled to Central Europe and the Balkans after the Bolshevik seizure of power. Led by the geographer and economist Petr Savitsky, the ethnographer Nikolai Trubetzkoy, and the historian George Vernadsky and containing linguists, philosophers and theologians, the Eurasianists were an eclectic mix of intellectuals. ${ }^{63}$ Simultaneously revolutionary and

\footnotetext{
${ }^{63}$ George Vernadsky is an especially important figure in the early Eurasianist movement not least of all because some of his work has been published in English. In 1927 he immigrated to the United States after being offered a position as an assistant professor of history at Yale University. During his life he wrote profusely on Russian history and historiography. In his work he argued that Russia was fundamentally different from the West. Rather, like the other Eurasianists, Vernadsky emphasized an Asian component that has always been present in Russian culture and politics. For more information see George Vernadsky, The Mongols and Russia (London: Oxford University Press, 1953), George Vernadsky, Kievan Russia (New Haven: Yale University Press, 1973) and
} 
conservative and fascinated by Benito Mussolini's Fascist experiment in Italy, they articulated a complex critique of previous notions of Russian identity while maintaining Russia's "otherness" from Europe. ${ }^{64}$ Fundamentally, the Eurasianists posited a romantic territoriallybased mythomoteur that theorized that Russian history, as well as Russianness, was defined by the territory it occupied.

Despite their unique approach to Russian history, the movement itself made little impact on contemporary discourse. This was in part because of the movement's factionalism; the Eurasianists were deeply split on their approach to communism and the Bolshevik victory in 1922. ${ }^{65}$ Some Eurasianists, devoted Orthodox Christians and critics of rationalism, were deeply skeptical of the atheistic and materialistic worldview espoused by communism. Thus for Trubetzkoy and others of like mind the Soviet Union was an eternal enemy. After the communist victory in the civil war many contemporaries feared that the red menace would spread successfully to the rest of the world. However, when the world revolution did not happen and the Soviet Union adopted the New Economic Policy some Eurasianists started to consider the Bolshevik revolution as not a truly communist one, but a Russian one. Seeing in the New Economic Policy as a more contained version of socialist economics and the Soviet Union as a multi-national state no longer encumbered by centuries of monarchy, many Eurasianists believed that with their influence the Soviet Union might be transformed into a state more suitable to their worldview. ${ }^{66}$ Others, more dubious, maintained that the Soviet Union was a manifestation of Russian "Westernism" and needed to be completely done away with. The Eurasianists never posited a comprehensive political platform. Indeed, they were never able to

George Vernadsky, A History of Russia (New Haven: Yale University Press, 1969).

${ }^{64}$ Marlene Laruelle, "The Orient in Russian Thought at the Turn of the Century" Russia Between East and West:

Scholarly Debates on Eurasianism, ed. Dmitry Schlapentokh (Leiden: Koniklijke Brill NV, 2007), 9.

${ }^{65}$ Laruelle, Russian Eurasianism, 23.

${ }^{66}$ Eldar Ismailov and Vladimer Papava, Rethinking Central Eurasia (Johns Hopkins University, SAIS, 2010$), 21$. 
decide as a whole whether or not Eurasianism should remain an academic school of thought or an actual popular movement. Nonetheless, taken as a whole the fractious proponents of Eurasianism proposed a new historical, quasi-religious and territorial myth-symbol complex for Russia.

The relationship between Russia and the east had been largely ambivalent throughout the Imperial period. Central and East Asia were largely seen as a target of territorial and economic expansion for the Russian empire. For the Russian state as well as many conservatives, Russia was culturally closer to Europe than Asia. The historiography of the contemporary Russian state traced its roots largely through Kievan Rus' and Muscovy. Russia was the "Third Rome," heir to the Greek Orthodox cultural and religious tradition. The Eurasianists, however, criticized the emphasis laid on Russia's Byzantine heritage as eurocentric and instead underscored Russia's Eastern heritage through a romanticizing of the Steppe and a historical heritage bequeathed by the Mongols and nomadism. Thus they distanced themselves from Slavophilism and Pan-Slavism, maintaining that non-Russian Slavdom was a part of Europe. They concluded that early Russian history was a meeting between "forest and steppe" - Russian and Turanian. ${ }^{67}$

Eurasianist historiography focuses on the Mongol Yoke period from the fourteenth through the sixteenth centuries. During this period all of the Russian states submitted to and became vassals of the Golden Horde. While other Russians decried this period in Russian history as a great injustice and lauded the heroics of Ivan III of Muscovy for finally ending Russian vassalage, the Eurasianists saw the Golden Horde's dominion as fundamentally healthy. During the period under the "Mongol Yoke," Eurasianists contended that many Russian nobles intermarried with members of the Golden Horde, which served to reawaken

\footnotetext{
${ }^{67}$ Laruelle, Russian Eurasianism, 41. The term "Turanian," is considered by some an obsolete term. It is largely an ethnic term that refers broadly to those of Turkic and Mongolian descent.
} 
Russia's true identity. Sedentary village life, the hallmark of life for many conservatives, was to be replaced by a nomadism of the spirit. ${ }^{68}$ With the retreat of the Golden Horde and the collapse of Mongolian hegemony over much of the Eurasian continent, it became the Russian people's mission to reunite much of the Mongol world. Russia's identity as a universal unifier was presumably inherited from its Mongol past. The Mongol Empire at its furthest extent stretched from what is now Manchuria to the Hungarian plains and from southern Siberia to the Himalaya Mountains. Some Eurasianists believed that it was Russia's destiny to rule over a similarly sized space. Russia's geographic position, like that of the Mongol Khanate of Genghis and Kublai Khan, gave it a certain historical predilection for empire building.

However, this new empire that the Russians were destined to build was not to be one that necessarily centered purely on Russian interests. Rather, it was to a universal empire. Indeed, Russia could not exist authentically without empire. ${ }^{69}$ The Eurasianists believed that only a country that exhibited a dual nature, being of both the West and the East could be one of the successful "centers of the world."70 The Mongolian empire justly ruled over much of the Indo-Chinese world and at its height reached the Mediterranean world. Containing Christians, Muslims, Buddhists of varying shades and countless local religions, the realm conquered by Genghis Khan's was fashioned a "United Empire of Mankind."71 Because the Russians were now heir to the Mongol heritage, they too could form a universal empire that included countless nations and religions. This new Eurasian empire, encompassing as it did various peoples and religions, could not take on a single cultural or ethnic identity. Rather, the founding identity for this collective empire was a quasi-religious belief in the Eurasian people's unity through a common destiny. Russia, being neither fully of the West nor of the East, was the connecting element that fostered a universally just empire.

\footnotetext{
${ }^{68}$ Laruelle, Russian Eurasianism, 41.

${ }^{69}$ Ismailov and Papaca, Rethinking Central Eurasia, 21.

${ }^{70}$ Laruelle, Russian Eurasianism, 42.

${ }^{71}$ Laruelle, Russian Eurasianism, 42.
} 
The Eurasian mythomoteur, grounded as it was in a Mongolian and nomadic mythsymbol complex also drew heavily on the belief in the trait-forming abilities of territory and geography on peoples. Furthermore, they generally continued the narrative that the Russian (or Eurasian) world was a third continent - neither wholly European nor Asian. The Eurasianists maintained that geography was the chief means of explaining the unity of a greater Eurasian culture and that there was a fundamentally organic link between a geographic space and a people's culture. The geographer Petr Savitsky proposed the idea of "topogenesis," in order to prove scientifically a link between nature and human beings. ${ }^{72}$ Furthermore the pseudoscientific Russian discipline of geosophy claimed that human history was not necessarily determined by their environment and geography but rather that geography and human beings had a reciprocal relationship. Eurasianists contended that the soil could expose a hidden meaning of past and future events. The subtle determinism of geosophy and Savitsky's theory of topogenesis attributed a mystical culture-forming aspect to land that aided in the creation of national identities.

Despite the inability of the Eurasianists to indicate exactly what constituted the borders of Eurasia, Savitsky and other Eurasianists claimed that the natural unity of the Eurasian territory could be scientifically explained. They argued that Eurasia”...is the only country whose flora, fauna, soil, and climate are so perfectly harmonious..." and that it represented as yet an undiscovered natural law. ${ }^{73}$ Eurasia was composed of four horizontal botanical strips of land and soil extending from east to west; taiga, tundra, desert and steppe. These strips of land were intersected by three major plains: the Siberian plain, the Turkistan plain and the plain from the White Sea to the Caucasus. This diverse geographic system demanded an array of various methods for humans to sustain themselves be it through sedentary farming, hunting, or

\footnotetext{
${ }^{72}$ Laruelle, Russian Eurasianism, 32.

${ }^{73}$ Laruelle, Russian Eurasianism, 33.
} 
herding. Thus the geographic arrangement of Eurasia, according to Eurasianists, was a manifestation Eurasia's universal mission. The Russian steppe was perhaps the most important of the types of land present in Eurasia. The steppe, spanning horizontally along much of Central and East Asia across multiple civilizations, constituted Eurasia's own "horizontal" mission. The sheer scope of this geographic facet of Eurasia proved to the Eurasianists the inherent expansionist character of Russia.

While the early Eurasian mythomoteur maintained that Russians and non-Russian Eurasians were a historically-united community of destiny, some Eurasianist scholars also attempted to unite the various peoples of Eurasia through cultural and linguistic approaches. Of the Eurasianists only a few including Trubetzkoy believed that the Russian people were at least somewhat related to the Slavs of the Balkans with their linguistic and religious similarities. ${ }^{74}$ Conversely, other Eurasianists emphasized that despite the linguistic links between Russians and other Slavs, non-Russian Slavs belonged mostly to the RomanoGermanic cultural zone. The Russians, on the other hand, were part of a cultural zone that included Finno-Urgic and Turkic peoples. Indeed, the Eurasianists maintained that genetic and racial kinship was irrelevant to understanding identity; rather, what mattered was where a culture or language was originally formed. Thus the theory of topogenesis put forward by Savitsky maintained that geography was essential to understanding the evolution of cultures and languages. The Russians, having developed their language in Eurasia, were exclusively a Eurasian people.

Furthermore, the Eurasian peoples, linked as they were by geography and culture to one another, also exhibited a linguistic unity. The linguist Roman Jakobson used three major criteria to demonstrate a relative linguistic unity among the various Eurasian peoples; tone, correlation of palatalization, and territorial continuity. Eurasia, according to Jakobson, was an area whose

\footnotetext{
${ }^{74}$ Laruelle, Russian Eurasianism, 35.
} 
populace all spoke languages that lacked complex tone or palatalization. The various Eurasian languages, admitted Jakobson, might not have originated near one another and might remain diverse, but they were nonetheless evolving toward the same characteristics and shared the same large geographical space. ${ }^{75}$ Again, the importance of geography and its effect on language and culture to the early Eurasianists' worldview was paramount. ${ }^{76}$

The early Eurasianists of the interwar period never formed a unified doctrine. They were a collection of like-minded individuals who tended to be religious revolutionaries. They saw Russia as the historically destined unifier of Eurasia and envisioned an empire bereft of traditional monarchy as well as European parliamentary democracy and capitalism. They remained, however, largely devoted to Orthodoxy while paying homage to Eurasia's religious diversity. The Eurasianists proposed something of an authoritarian conception of a new Eurasian state, a diverse empire that represented a communal harmony between different cultures and religions but nonetheless all devoted to a single central government. They combined a romantic myth-symbol complex containing a cult of diversity with a mythomoteur that defined the Russian nation as a destined unifier of a great empire. Despite their failure to have an effect on the Soviet Union and their dispersal by the end of the Second World War, the early Eurasianists were in part a precursor to Alexander Dugin's own neo-Eurasianist philosophy.

While the Eurasianists posited a largely religious and cultural definition of Russianness, the ethnic theories of Lev Gumilev are an example of mythomoteur of the Russian nation that is defined purely by a biological determinism and social Darwinism. His work is said by some scholars such as Anton Shekhovtsov to have had a direct influence on the geopolitical theories

\footnotetext{
${ }^{75}$ Laruelle, Russian Eurasianism, 35.

${ }^{76}$ Like Vernadsky, Jakobson eventually immigrated to the United States and continued his academic career. For further information on Jakobson's linguistic research on Slavic languages see Roman Jakobson, Selected Writings VII, ed. Stephen Rudy (Berlin: Walter de Gruyter \& Co., 1985).
} 
of Alexander Dugin. ${ }^{77}$

Much of Gumilev's life was marked by political dissidence. From praising anti-Stalinist poetry to being implicated in a terrorist attack on a Leningrad party official, Gumilev was arrested and imprisoned in the forced labor camps of the Gulag system multiple times. Despite his history of arrests, he was able to become one of the most celebrated scholars in the Soviet Union after Stalin's death. Originally a scholar of East Asian history and culture who wrote extensively on the Huns and Mongols, Gumilev eventually developed an interest in broader questions of how societies and ethnicities develop and their relationship with one another. Ultimately, Gumilev developed a theory of history and ethnicity that was said to transcend the humanities, positing that human history could be predicted. ${ }^{78}$

In his book Ethnogensis and the Biosphere Gumilev presented an expansive explanation of how civilizations such as the Mongols, having been seemingly quiet and calm for so long, erupted into a great frenzy of activity, conquering huge swathes of land and ruling other civilizations only to collapse just as suddenly. His answer to this question was what he called "passionarity." This phenomenon, determined largely by natural forces such as the undulation of solar radiation levels, gives great bursts of activity and inspiration to certain peoples depending on where they live on the globe. ${ }^{79}$ This passionarity leads to bursts of artistic and architectural achievements as well as to the creation of great empires. Ethnic groups, hithero seen by outsiders as mostly isolated and unassuming, in a burst of passionarity were able to form complex state systems and advanced military technologies to defeat and conquer their neighbors. ${ }^{80}$ Each ethnic group can then be seen as vessels of individuals who are

\footnotetext{
77 Anton Shekhovtsov, “Aleksander Dugin's Neo-Eurasianism: The New Right à la Russe?” Religious Compass no. 3 (Blackwell Publishing Ltd., 2009), 704.

${ }^{78}$ Laruelle, Russian Eurasianism, 62.

${ }^{79}$ Alexander Yanov, “The 'Enlightened' Nationalism of Lev Gumilev, Institute of Modern Russia, (December, 2012) $<$ http://imrussia.org/en/society/613 $>$

80 "Prominent Russians: Lev Gumilev," RT Russipedia, $<$ http://russiapedia.rt.com/prominent-russians/science and-technology/lev-gumilev/>.
} 
themselves vessels of the ethnic group's potential for passionarity; such individuals include Napoleon Bonaparte, Alexander the Great, and Genghis Khan. The ethnic group, what Gumilev called the "ethnos," then, was a biological and organic entity that could be observed as collective whole. However, individuals and great leaders within the ethnos represent a sort of soul or spirit of the rest of the ethnos and led it to do great things. ${ }^{81}$ They are fundamentally unconscious bearers of the ethnos' greater will.

According to Gumilev, it is a scientific reality that each ethnic group has a prescribed lifespan from 1,200 to 1,500 years. ${ }^{82}$ Once an ethnic group emerged, it went through a series of pre-determined life stages not unlike the life stages of a human being. Ethnogenesis is divided into several life stages; the first three hundred years of an ethnos' life is its early "childhood." After that, another three hundred years of adolescence characterizes the second stage. Thirdly, the ethnos goes through one hundred and fifty years of conquest. After that, there is six hundred years of consolidation in which the ethnos acquires an ideological foundation and a reliance on technology but dies spiritually and internally. The final two stages of an ethnos' lifespan are characterized by a gradual decline and the extinction of the group or it becoming a sort of "relic" like the Australian aborigines. ${ }^{83}$ Thus human history was largely pre-determined by biological and solar factors.

Placing the theory of ethnogenesis into a historical context, Gumilev's historiography resembles that of the interwar Eurasianists. Like the Eurasianists, he saw Russia as a constitutive part of a larger Eurasian identity. He believed that during the sixteenth centuries the Russians, Mongols and Tatars came together to form a larger ethnic group, or a super-ethnos. One thousand years prior to the formation of the Eurasian super-ethnos a Latin-Germanic

\footnotetext{
81 “Prominent Russians: Lev Gumilev," RT Russipedia, < $\underline{\text { http://russiapedia.rt.com/prominent-russians/science- }}$ and-technology/lev-gumilev/>.

82 "Prominent Russians: Lev Gumilev," RT Russipedia, < $\underline{\text { http://russiapedia.rt.com/prominent-russians/science- }}$ and-technology/lev-gumilev/>.

${ }^{83}$ Laruelle, Russian Eurasianism, 69.
} 
super-ethnos was formed in Western Europe which came to represent a constant threat to the Eurasian one. While one current in Russian historiography praises Russia for defeating the Mongols and thus saving the rest of Christendom, Gumilev emphasized that it was rather fortuitous that the Mongols had invaded Russia which was then protected and insulated from a Western invasion. Like the early Eurasianists, Gumilev praised the Mongols of the Golden Horde, maintaining that their religious tolerance allowed the Russians to maintain their organic ties with Orthodox Christianity. ${ }^{84}$ The Mongol period is described as a healthy symbiotic relationship between the Russians and the Mongols. The period served to protect and strengthen the Russian ethnos. However, according to Gumilev, once the Golden Horde adopted Islam it attached itself to another super-ethnos, an Islamic one. Thus, the Russians became heir to an empire of the Steppes. Marlene Laruelle correctly notes that this represents one of the many contradictions within Gumilev's theory of ethnogenesis. ${ }^{85}$ If ethnogenesis is a fundamentally biological process that can be scientifically observed, then how can the inclusion and exclusion of an ethnos into a super-ethnos be based on the assumption of a new faith? Moreover, Gumilev's ideas on the positive results of Russian mixing with Turks and Mongols throughout history only go so far. Whereas the Eurasianists were content with the idea of Russians having a biological blood tie to Mongols and other Asian peoples, Gumilev stressed the importance of keeping ethnic groups biologically separated and championed endogamy. With interbreeding came the dilution of the gene pool and the ethnos' potential passionarity. This biological sentiment was quite unlike the Eurasiansts' own romantic sentiments concerning the relationship between Russia and its neighbors.

Despite the contradictions within his own historiosophy when taking into account his theory of ethnogenesis, Gumilev's conception of Russian nationhood largely resembles that of

\footnotetext{
${ }^{84}$ Yanov. $<$ http://imrussia.org/en/society/613 $>$.

${ }^{85}$ Laruelle, Russian Eurasianism, 72.
} 
the Eurasianists. Both espouse a belief that the Russian nation, be it through a community of destiny or a deterministic cultural fusion of Russian and Central Asian ethnic groups, is only authentically realized as part of a larger whole. Both the Eurasianists and Gumilev professed a belief in the supremacy of the organic community over individuals throughout history. In addition, both Eurasianists and Gumilev completely rejected a European identity for Russia, and rather emphasized that Russia was a category unto itself that embraced an Eastern heritage more than a Western one.

In approaching both interwar Eurasianism and the theories espoused by Lev Gumilev, it is easy to see the similarities between them and the work of Alexander Dugin. All three espouse a belief in the uniqueness of a communitarian Russia. Furthermore Eurasianism as well as Gumilev and Dugin see the expansion of Russian territory as natural and desirable even pre-destined. Thirdly, all three see the West, or at least many of the ideas produced there, as a threat to Russia. The main point of divergence between the three set of ideas is the question of race. While the Eurasianists and Dugin, as will be discussed later, define the Eurasian community in largely religious or cultural terms, Gumilev unequivocally maintains a racial view of man. Indeed, Gumilev's historical philosophy can be seen as a case for biological determinism that leaves little room for God or spirituality. Unlike Dugin's ideas, Gumilev's theories are scientifically reductionist in their argument that an ethnic group's actions and history are essentially predetermined by their level of passionarity. 


\subsection{The European New Right}

On May 21, 2013 the French right-wing historian Dominque Venner committed suicide. In the midst of around 1,500 other people in and around the Notre Dame Cathedral, he shot himself at its altar. A determined opponent to the recent legalization of gay marriage and a vehement activist against the influx of non-European immigrants to France, Venner believed that only through a violent and shocking display could he awaken the French masses from their apathy. ${ }^{86} \mathrm{~A}$ historian and political activist, Venner worked with Alain de Benoist along with other members of the far right. The shocking suicide let to an outpour of sentiment from politicians and thinkers of the right. Marine le Pen, the leader of the Front Nationale, a socially conservative and nationalist party, and the rightist academic Bruno Gollnisch expressed their deepest sympathies. Less than twenty-four hours after Venner's suicide, however, the feminist group Femen staged a mock suicide at the cathedral; a topless demonstration with "may fascists rest in hell" written on their chests. ${ }^{87}$

Venner's suicide represents only one instance of a call to action that has resonated in much of the post-war right. Disparaging of liberal democracy and decrying what they see as the homogenization of particular European identities, members of the far right throughout the Western world have been calling for a complete transformation of the global order. Against American global hegemony, consumerism and multiculturalism they propose a multi-polar world that would mean the end of American cultural and political influence. Despite a generally agreed-upon platform of what they are against, the contemporary far right is deeply fragmented. Some on the far right are no more than isolated would-be terrorists who maintain that the only way to affect real change is through violent action against the state, political opponents, and

\footnotetext{
${ }^{86}$ Christian Fraser, “France Reacts to Dominique Venner's 'Shock' Gesture,” BBC News May 27, 2013 http://www.bbc.com/news/world-europe-22628159.

${ }^{87}$ Kim Wilsher, "Femen Protester Stages Mock Suicide at Notre Dame Cathedral," The Guardian May 222013 http://www.theguardian.com/world/2013/may/22/femen-mock-suicide-notre-dame.
} 
immigrants. Others such as the Greek political party Golden Dawn utilize Nazi paraphernalia such as the swastika and Hitler salute to shock spectators. Still others, however, follow a more cautious and long-term approach to competing for political power. Described by many observers as the New Right, this group is composed of academics and intellectuals who are critics of liberalism and modernity. Inspired by the Italian communist Antonio Gramsci, they have appropriated his approach to gaining power by attempting to participate in a new type of politics. While many political and interest groups attempt to gain power through elections or even sometimes force, the New Right maintains that the only way to affect real change is by gaining cultural hegemony by changing the values of elites through educational and media institutions. Thus the European New Right's fundamental strategy is borrowed from the left.

One of the most important intellectual organs of the New Right is the Groupement de Recherche et d'Etudes pour la Civilisation Européenne or the Research and Study Group for European Civilization (GRECE). Founded in 1968 by the writer and journalist Alain de Benoist, it is a religious and nationalist think tank that has been the most important venue for far right discourse for the past half century. Founded by forty individuals from separate nationalist and dissident groups, GRECE formed a discourse that has challenged contemporary accepted political and social norms and formed a stage upon which other like-minded rightists could participate through their journals Éléments and Nouvelle École. Intellectuals of the European New Right have for the past decades participated in multiple conferences and debates, platforms in which intellectuals from different countries can participate. As early as 1992, Alexander Dugin and Alain de Benoist have had a cordial relationship. While never always in full agreement with Benoist, Dugin's own journal was clearly inspired by Benoist's É Éments.

One of the means by which the European New Right has sought to overturn what it perceives to be the apathy of European peoples concerning globalization and the loss of individual cultures' particularities is through spiritual revival. However, while many of the far 
right, particularly the reactionary right, have usually championed Christianity as Europe's traditional religion, many New Rightists denounce Christianity as one of the chief problems of contemporary Western society. Rather, many among the New Right look to the revival of ancient European paganism with its vitalism and cult of masculinity as one of the only means of restoring Europe's sense of self. The New Right's hostility towards Christianity can be explained by examining its historiosophy, how it emplots European history and how they conceptualizes time.

According to the New Right the natural religion of the European peoples is paganism. Various tribes worshipped different gods and practiced different rites. Nonetheless, all the preChristian tribal religions shared a reverence for nature, heroism, and believed that "life has no purpose other than itself." 88 Furthermore, they believed in the cyclical nature of time and peoples; like the seasons peoples and eras go through an endless cycle of birth, death, and rebirth. The numerous European pagan practices prior to the advent of Christianity, then, contained a cult of action and a morality system that allowed for shades of grey rather than absolute criteria in appraising right and wrong. Truth to the pagan was not a universal truth, and what was good and what was evil was not an objective reality, but subjective and dependent on many variables. Furthermore, the gods of a particular tribe or nation were just that; theirs. European pagans had no use for evangelical missions or holy wars. Accordingly, the New Right asserts, paganism was given to more nuance than Christianity is, and Europe's traditional religions were thus more open-minded and tolerant of other peoples and ways of life.

The New Right argues that truth and morality were subjective ideas to European pagans, and it was not necessary to reify those concepts. However, how one conducted oneself was not subjective. No matter what the circumstance the pre-Christian pagan always valued honor,

${ }^{88}$ Michael O’Meara, New Culture, New Right (London: Arktos, 2013), 130. 
loyalty, and heroism and disparaged cowardice. ${ }^{89}$ Figures such as Alain de Benoist contend that paganism was a religion of works, not one of faith. Even with the introduction of Christianity the European peoples were only converted after a combination of bribery, torture, and trickery. Ultimately, the only way that Christianity could take hold in Europe was through adaptation to the European situation, depicting Christ not as a fallen god but focused on the resurrected aspect of Christ, seeing him as a god of victory. ${ }^{90}$

Just like Nietzsche, Alain de Benoist sees Christianity's more or less dominance of European culture as nothing less than "catastrophic." ${ }^{11}$ For him, it is the cause of the unrealistic egalitarian universalism seen in both Marxism and liberalism that has led to the deracination and slow death of European civilization. Christianity, an oriental "desert religion" was and remains an alien religion opposed to the vitality and life-affirming spirituality of European forest dwellers. Christianity represents nothing less than the complete dismantlement of the European spirit and is ultimately a totalitarian doctrine. New Rightists maintain that Christianity's disastrous consequences can be seen throughout European history all the way to the mass murders and gulag system of the Soviet Union. Christianity's conceptualization of time and history, that existence had a definite starting point and a fixed, divinely determined end point has doomed the European peoples to a false sense of reality. Mono-linear time, as opposed to pagan ideas of cyclical time, then, creates a narrative of progress which maintains that eventually the whole world will be led into a utopia; Christ's millennial reign. In addition to its opposition to Christianity's sense of progress and time, the New Right argues against Christianity's metaphysical dualism. Maintaining that European paganism valued diversity through its variety of tribal deities and its lack of evangelical spirit, the New Right claims that Christianity changed the way Europeans thought about reality. Christianity introduced a

${ }^{89}$ O’Meara, New Culture, New Right, 130.

${ }^{90}$ O'Meara, New Culture, New Right, 126.

${ }^{91}$ Alain de Benoist, On Being a Pagan (Atlanta: Ultra, 2005), 1. 
stringent definition of the truth; questions of morality were seen in shades of black and white with seldom any nuance. ${ }^{92}$ By cutting themselves off from their pagan roots, Christian Europeans began to believe in the equality of all souls before God, and similarly, believed in an evangelizing mission to convert all souls to a one true God. ${ }^{93}$ This "Bolshevism of Antiquity," according to the New Right, would later be secularized and utilized for other universal missions. $^{94}$

The New Right has created a historical narrative that holds the advent of Christianity and its direct epistemological effects on the formation of modern ideologies such as liberalism and Marxism as directly responsible for what it sees as the slow death of particularism today. In short, they argue that the Late Middle Ages was the last time traditional pagan virtues held any real influence on European civilization. During this period, the pagan ideals of a warrior king, honor and loyalty were still ensconced in the popular ideals of chivalry and divinely ordained kingship. However, the Reformation marked the final blow to European paganism. With the rise of first Lutheranism and then other forms of Protestantism, Christianity as a whole unwittingly let loose the floodgates to skepticism, which led to the necessity to tolerate individual interpretations of the Bible, spiritual ennui and finally secularism. This secularism manifested itself initially as a new societal focus on science. Renaissance humanism gave way to an increasingly rationalistic approach to the world. The natural world then became “...measured, analyzed and rendered into the language of mathematics." 95 Eventually, rationalism was utilized as a universal model to be applied to society and the state. Rationalism became a part of the discourse of revolutionaries of what would later be known as the "left," which sought overturn centuries-old traditions and hierarchies.

Since the seventeenth century, according to the New Right, science and rationalism

\footnotetext{
92 David Miller, The New Polytheism (New York: Harper and Row, 1974), 7.

${ }^{93}$ Sunic, Against Democracy and Equality, 112.

${ }^{94}$ Sunic, Against Democracy and Equality, 112.

${ }^{95}$ O’Meara New Culture, New Right, 13.
} 
have effectively replaced spiritual values and tradition as the legitimizing ideas behind authority and statehood. The rise of capitalism, intellectually justified by Protestantism and rationalism, combined with further religious dissolution and the centralizing tendencies of monarchs to create new societies. The new model of the state was created in order to maximize administrative efficiency and economic profit, regardless of a culturally-specific common good. This secular rationalism was manifested in the liberalism of the eighteenth century and the French revolution. Positing a secular universalism, liberalism and later Marxism declared their materialistic doctrines to be universally applicable and historically determined.${ }^{96}$ Furthermore, the false narrative of eternal progress present in liberalism and Marxism both foster a culture of "liberation," which according to the New Right, strives towards ever-more spurious "liberations." Starting with an emancipation from God or the divine, liberalism has created a culture in which ethnic, cultural, and gender identities, once considered natural and inherent to the individual, are easily taken up and discarded at will in the name of a postmodern cult of individualism.

The New Right, embodied in GRECE, is also deeply critical of contemporary conceptions of democracy. In place of what they see as an American-centric idea of democracy that is used as a universal model, they argue for a diversity of government types, maintaining that different peoples require different forms of government. In The Problem of Democracy, Benoist argues for an ethnic understanding of the history of democracy. He maintains that democratic tendencies among pre-modern peoples such as Athenian Greeks and Norse Icelanders were founded upon a common rootedness. Citizenship and participation in politics was a manifestation of their belonging to a common homeland and sharing a common background, thus endowing them with common interests. ${ }^{97}$ In essence, there was a "cultural

\footnotetext{
${ }^{96}$ O’Meara New Culture, New Right, 12.

${ }^{97}$ Alain de Benoist, The Problems of Democracy (London: Arktos, 2011), 28.
} 
cohesion" in Athens and other city-states. ${ }^{98}$ Sharing common interests, values, myths, histories and a shared homeland, the peoples of the Greek city-states were able to effectively administer themselves democratically while still respecting hierarchy and tradition. In contrast, the modern democratic process is organized around atomized individuals selfishly competing for personal interests with no regard for the greater community. ${ }^{99}$ Indeed, contemporary European countries such as France and the United Kingdom, inundated as they are with foreign immigrants no longer represent societies for which the first iteration of democracy was meant for.

Seeing in Europe a crisis of identity and a threat to its survival, the European New Right has created a fundamentally new mythomoteur and myth-symbol complex to articulate a European identity. Opposed to what they see as the universalism of Christianity that has manifested itself in virtually all left-wing projects, GRECE has created a pre-Christian mythsymbol complex that extolls the virtues of a diverse European paganism. Utilizing mostly Norse mythological symbols, images of Odin, ravens, and runes have become an important component of the New Right's call for Europeans to revert back to their ancestral roots. ${ }^{100}$ Paradoxically, the New Right has utilized a narrative of pre-Christian Europe's religious diversity to unite culturally disparate peoples into a supra-national identity. Furthermore, the GRECE mythomoteur uses a fall-redemption narrative that details an idealized pagan Europe that has been duped or forced into accepting culture-killing Christianity and its inevitably totalitarian ideologies of Marxism and liberalism. Embodied by the rootless and mercantile United States, Europe has been subjected to a slow spiritual and ethnic death. Only through the

\footnotetext{
${ }^{98}$ Benoist, The Problems of Democracy, 28.

${ }^{99}$ Benoist, The Problems of Democracy, 27.

${ }^{100}$ This is particularly true in the case of the more vulgar White Power movements in the United States and Europe. Wotanism, a religion espoused by members of the white terrorist group The Order such as David Lane have repackaged Norse polytheism as a whites-only religion. For a summary of the more militant American version of the New Right's mythological myth-symbol complex see Mattias Gardell, Gods of the Blood: The Pagan Revival and White Separatism (Durham: Duke University Press, 2003) and Ron McVan, Creed of Iron (Creative Space Publishing, 2012).
} 
revitalization of its sense of self through pagan spirituality and an appreciation of their common history can European peoples unite under a federal system that defends their particularities against the vagaries of modernity.

Today the New Right is not only represented by GRECE members but a diverse group of thinkers largely in Europe as well as North America. Communicating through online webzines, podcasts and journals, they all share a deep distrust of modern society and American hegemony as well as a profound dislike of multiculturalism. While some such as Benoist call for a resurrection of Europe's Pagan past, others are more comfortable remaining with Christianity. Still others like Alexander Dugin, inspired by the extreme anti-modernism of Julius Evola and other Traditionalists, have turned to the reactionary doctrine of Traditionalism in an attempt to exorcise the modern demons of contemporary Western society.

On the surface, Neo-Eurasianism as espoused by Dugin is another example of Russian nationalist nostalgia. For some, the Russian Empire of the nineteenth century and before represented a golden age of traditional Russian values. For others, the Soviet Union was the ideal guarantor of Soviet, and thus Russian, great power status. Dugin is indeed nostalgic. However, while Dugin truly mourns the dissolution of the Soviet Empire, likening Russia to Germany right after the First World War, his expansionist project utilizes neither Tsarist nor Soviet symbols. ${ }^{101}$ Rather, Dugin mourns the tragedy of what he sees as a truly global loss. Modernity and liberalism, he argues, have deprived humanity of its connection to the sacred, and have stripped many cultures of their natural, divinely-ordained traditions, religions, and hierarchies. His ideas are fundamentally grounded in a genuine belief in a Perennial Tradition as articulated by René Guénon and Julius Evola.

Some scholars, such as Marlene Laruelle and Edith Clowes have argued for a more

${ }^{101}$ John B. Dunlop, “Alexander Dugin's Foundations of Geopolitics" in The Fourth Political Theory: Beyond Left and Right but Against the Center $<$ http://www.4pt.su/en/content/aleksandr-dugin $\% \mathrm{E} 2 \% 80 \% 99 \mathrm{~s}-$ foundations-geopolitics> 
ethnic or even racial understanding of Dugin's type of nationalism. He does, after all, maintain that Russians are perhaps the most important part of any Eurasianist project and utilizes much of the same language that interwar German racists and Aryan supremacists used. However, it is imperative to place Dugin's ideas within his religious worldview. Dugin's religious outlook is the most important part of his intellectual makeup. It separates him from the primarily Orthodox early Eurasianists and Gumilev's racial and biological conception of nationhood and other forms of Russian nationalism. Instead, Dugin approaches nationhood through a mystical prism that posits that nations are defined by participation in a culture's traditional religion and sacred geography. His Traditionalist worldview can be seen in what he calls The Fourth Political Theory and his mystical geopolitical theories. 


\section{Chapter 3: Perennial Traditionalism and Dugin's Neo-Eurasianism}

Perennial Traditionalism is a religious philosophy that maintains that most of the world's religions share a single universal truth which is the foundation for all religious knowledge. As a worldview that allows for diverse representations of that truth, it can be said to characterize many religious and political dissidents of the twentieth century who saw in modernity a universal fall from grace. The origins of the idea of a Perennial Tradition can be traced to the Renaissance era. Martin Sedgwick's work, Against the Modern World: Traditionalism and the Secret Intellectual History of the Twentieth Century, points out that the term philosophia perennis (Perennial Philosophy) was used in 1540 by a Catholic scholar to explain one of the main ideas proposed by Marsilio Ficino. ${ }^{102}$ Ficino believed that the revival of Plato and his ideas as an object of discussion was a gift from God to offer philosophical arguments for Christianity. Ficino, then, elevated Plato beside Christianity as having equal authority as both were "lawful" religions. ${ }^{103}$

According to Ficino, Zoroastrianism, Christianity, Judaism and native pagan religions all shared a spiritual lineage dating back to a foundational spiritual truth. ${ }^{104}$ This spiritual truth was founded on the alleged discovery of theological writings supposedly written by Hermes Trismegistus, a mythical ancient pagan thought to be a contemporary of Moses. Trismegistus also supposedly practiced a belief in a universal truth as well as alchemy, which further helped Ficino popularize his belief in a perennial philosophy. ${ }^{105}$ His writings, later discovered to be forgeries, were translated by Ficino. They provided a means of religious syncretism; the rites of paganism, Jewish Kabballah, and later Islam and Hinduism were practiced by religious Traditionalists who saw them all as expressions of a larger universal and divine truth.

\footnotetext{
${ }^{102}$ Mark Sedgwick, Against the Modern World: Traditionalism and the Secret Intellectual History of the Twentieth Century (Oxford: Oxford University Press, 2004), 23.

${ }^{103}$ Sedgwick, 24.

${ }^{104}$ Sedgwick, 24.

${ }^{105}$ Heiser, 19.
} 
Traditionalism as a syncretic religious belief has survived in various forms through secret societies and occult ideologies into the twenty first-century.

In an interview on May 17, 2014 with Open Revolt a North American-based organization that supports Alexander Dugin's Fourth Political Theory, Dugin explained his intellectual background;

“...In my early youth I was deeply inspired by Traditionalism of Rene Guenon and Julius Evola. That was my definitive choice of camp - on the side of sacred Tradition against the modern (and post-modern) world. This choice and all consequences are still there in the present. I firmly stand for spiritual and religious values against actual decadent materialist and perverted culture. Traditionalism was and rests central as the philosophic focus of all my later developments." 106

René Guénon was the first major Traditionalist thinker of the first half of the twentieth century. An Indologist who sought to prove Hinduism's Traditional origins, Guénon was deeply pessimistic about the course of Western civilization. Modernity, Guénon argued, postulated a false narrative of progress that was typified by democracy and Marxism. However according to Guénon the modern age was actually a dark age of humanity - what Hindus called the Kali Yuga. ${ }^{107}$ Guénon believed that prior to the advent of modernity and its hedonistic individualism individuals and society were closer to a universal god through a society's local religious tradition. Correct, divinely-ordained traditions of hierarchy, proper gender relations, and humility were established. Modernity with its secularism and emphasis on rationalism and egalitarianism had effectively severed much of humanity's connection to the divine. He stressed the "initiatic" potential of Traditionalism. ${ }^{108}$ Only through the proper initiation of an individual into Tradition, drawing on rituals and doctrine that still maintained a fragment of the

\footnotetext{
106 “The Long Path: An Interview with Alexander Dugin, Open Revolt, $<$ http://openrevolt.info/2014/05/17/alexander-dugin-interview/>.

107 Sedgwick, 24.

${ }^{108}$ Sedgwick, 25.
} 
Perennial Tradition, could an individual begin to find his way back to the divine. However, Western society, being the birthplace of modernity, was also the least likely to recover spiritual authenticity - particularly due to Christianity having been largely subjugated by modernity. Rather, Guénon called on Eastern religions, whose connection to the Perennial Tradition had as of yet not been sullied by modern rationalism to bring salvation to the West and save Western civilization. ${ }^{109}$ Although he eventually converted to Sufi Islam and lived out his life in Egypt, Guénon for a time believed that Hinduism was the religion through which the West could rediscover its connection to Tradition.

Especially appealing to Guénon and later, Julius Evola, was the strict hierarchical nature of Hinduism. Julius Evola was a philosopher who also dabbled in magic and alchemy which he considered a Traditional pre-modern science. ${ }^{110}$ Evola envisioned a largely mythic preChristian Europe in a world in which authority and the divine were indivisible. In his famous work, Revolt Against the Modern World, Evola claimed that kingship and aristocracy were divinely sanctioned and necessary for any society to function. A tribal chief or king's central role was to be a conduit to the divine and thus his "primary and essential function consisted in performing those ritual and sacrificial actions that constituted the center of gravity of all life..."111 For such a king, Traditional life was a global reality: From the Far Eastern concept of "the son of Heaven" to the deification of Roman emperors and the pre-modern Christian belief in divine kingship, authority was enshrined as a natural and sacred facet of human relations. A king or ruler was also a high priest and functioned as a conduit to the celestial. Thus for Evola authority had a metaphysical nature and temporal power proceeded from its spiritual authority. ${ }^{112}$

\footnotetext{
109 Sedgwick, 25.

${ }^{110}$ Sedgwick, 103.

${ }^{111}$ Julius Evola, Revolt Against the Modern World, trans. Guido Stucco (Rochester: Inner Traditions International, 1995), 11.

${ }^{112}$ Nicholas Goodrick-Clarke, Black Sun: Aryan Cults, Esoteric Nazism and the Politics of Idenity (New York: New York University Press, 2002), ch. 3. Ebook.
} 
Although Evola eventually became an advocate for Europe's return to its own pagan beliefs, the syncretic nature of Traditionalism allowed him to draw heavily on other religions, particularly Hinduism. In early Hinduism, Evola saw a society in which caste, hierarchy, religious rites and natural forms of authority were supreme over individualism and materialism. Invoking what he saw as a mythical, masculine and sacred tradition, Hinduism was one of the few religions remaining that had kept a measure of its Traditional truth. Furthermore, like many non-monotheist religions Hinduism approached time as cyclical. For Evola, existence and civilizations go through endless cycles of birth, growth, aging, death and rebirth. Accordingly, just like Guénon, Evola saw the modern world as going through a stage of Kali Yuga, in which discord, chaos, and vice reign supreme.

Evola was a contemporary of Adolf Hitler and Benito Mussolini who preached a mystical ideology that combined a doctrine of political elitism, masculine aristocracy, and Perennial Traditionalism. ${ }^{113}$ An early supporter of both Italian Fascism and National Socialism, he nonetheless grew weary of both ideologies. This was because Evola ultimately believed that while fascism and National Socialism made important strides in reinvigorating Europe with a cult of action, neither ideology fostered a truly Traditional spirituality. Rather, both movements were far too populist and, despite the apparent attempts by the Nazi Reich to form a new elite class of warriors such as the SS, did not do enough to foster a truly aristocratic principle. ${ }^{114}$

Furthermore, Evola was deeply disappointed with Nazism's biological determinism and racism. Indeed, an important note must be made concerning Evola, the history of Nazism and the subject of race. Evola certainly espoused a fundamentally anti-Semitic worldview. However, an essential distinction that must be made is that Evola was principally against what he called "Semitic thought." 115 That is ideas such as egalitarianism, materialism, and secularism

\footnotetext{
${ }^{113}$ Nicholas Goodrick-Clarke, The Occult Roots of Nazism: Secret Aryan Cults and their Influence on Nazi Ideology (New York: New York University Press, 1992), 190.

114 Sedgwick, 107.

${ }^{115}$ A. James Gregor, Mussolini's Intellectuals: Fascist Social and Political Thought (Princeton: Princeton
} 
entertained by many Jews as well as those who had a similar "Semitic" mentality. Countering the "Semitic" mentality was an "Aryan" mindset that valued honor, loyalty, hierarchy and tradition. Race to Evola was not the biological or ethnic substance of a group of people, but rather was a spiritual phenomenon. While ethnic groups carried a "memory" of a spiritual race, there was nothing inherently noble or superior about an Aryan man. Rather, only by adopting the values of an Aryan mindset could someone become an Aryan. Simply because a man came from Nordic stock did not necessarily mean he was "Aryan" of spirit. ${ }^{116}$ Indeed, he scoffed at the idea that a contemporary German street sweeper would consider himself better than an African king purely on the basis of his white skin. ${ }^{117}$ Indeed, Jews could be spiritually superior to many non-Jews. While Hitler's definition of Aryan largely included those only of a Germanic ethnic background, Evola maintained that Hitler himself was not Aryan as he was a demagogue and populist. ${ }^{118}$ Hitler's populist National Socialist movement was "proletarianized" and accepted only a "completely plebeian" concept of race. ${ }^{119}$ Opposed to ethnic anti-Semitism, Evola argued that the primary indicator of human character was not racial or genetic makeup, but rather a person's spiritual life and outlook. ${ }^{120}$ Therefore in Evola's writings an "Aryan" or "Jew" should not be understood as purely biological entities, "but as categories denoting 'typical attitudes which were not necessarily present in all individuals of Aryan or Jewish blood." "121 This is not to say that Evola's ideas were not deeply wrong, but his distinction between spiritual and biological race allows for the possibility for someone like Dugin to read Evola's ideas on race as primarily religious and otherworldly, rather than biological.

\footnotetext{
University Press, 2005), Ebook.

116 Gregor, Mussolini's Intellectuals, Ebook.

${ }^{117}$ Julius Evola, Notes on the Third Reich trans. Christian Koph (London: Arktos, 2013), Ebook.

${ }^{118}$ Evola, Notes on the Third Reich.

${ }^{119}$ Evola, Notes on the Third Reich.

${ }^{120}$ Sedgwick, 107.

${ }^{121}$ Quoted in Ibid.
} 
Like Evola, Dugin fears that contemporary society exists in the Kali Yuga. In his 2001 manifesto of the Eurasianist Movement, Dugin decried a fallen world in which totalitarian uniformity and consumerism are the only hallmarks of the modern life. ${ }^{122}$ Additionally angered by the seeming political and ideological apathy of the masses, he wrote, "The majority of political parties and formalized social movements pursue tactical purposes. Practically nowhere can be found an explicit and consequent ideology capable to snatch man from a state of sleepy indifference, to make life worth living." 123

For Dugin, this philosophical ennui has been largely fostered by the victory of American liberal democracy and Americanization of the cultures of the world, which he describes as an "Atlanticist tsunami." ${ }^{124}$ In addition to what he sees as the death of ideology, Dugin also mourns the dissolution of the Soviet Union, which he regards an unmitigated disaster. The end of the Soviet Union meant the effective end of organized opposition to globalization and Americanization. However, rather than a restoration of the Soviet Union Dugin proposes a new political union, a Eurasian one. A Eurasianist empire would stretch into territories and countries that neither the Russian Empire nor the Soviet Union had ever ruled over. The Eurasianist movement represents a supranational project that will unite many different religions and ethnic groups into a single empire. On the surface, Dugin's geopolitical vision appears to be driven by a desire for the maximization of Russian power and influence. To some extent, that is correct. However, pregnant within Dugin's territorial ambitions for a Eurasianist empire are Traditional ideas of sacred space as well as a new ideological model of identity. The model incorporates ideas of both civilization and the spiritual missions of peoples as constitutive facets of identity. The Eurasianist project ultimately posits a new mythomoteur for Russians by portraying Russia as an important "glue" to a greater Eurasian empire, thus fulfilling its divinely-ordained

\footnotetext{
${ }^{122}$ Alexander Dugin, Eurasia Above All: Manifest of the Eurasist Movement, http://webcache.googleusercontent.com/search?q=cache:http://arctogaia.com/public/eng/Manifesto.html. 123 Ibid. 124 Ibid.
} 
mission - to be a uniter of peoples.

Dugin's arguments for a civilizational model of history discussed in his The Fourth Political Theory are not purely made for the strengthening of Russian state power. Rather, his definition of the Russian nation and its role within a greater Eurasian civilization are determined by his esoteric belief in the Perennial Tradition. Dugin's definition of Russian nationhood is fundamentally spiritual. Indeed, Dugin has often repeated his disagreement with racism and the notion of race itself. Rather, he posits that the Russian nation is and must be defined as a spiritually-rooted people practicing Orthodoxy as it remains one of the few Christian traditions that have held on to some Traditional truth. He argues, "Russians should realize that they are Orthodox in the first place." 125 Furthermore, Russians, like all other nations, are represented by angels. According to Dugin's Traditionalism, these "national angels" determine the character of individual nations and are representatives of "God's thought."126 Russia is depicted as an "integration angel;" a divine unifying essence that collects other national angels into a "universal imperial" project that protects the individuality of each of the angels. ${ }^{127}$ Conversely, the Anglo-Saxon West opposes it with its own type of angel called "mammon," a god of greed. ${ }^{128}$ Thus utilizing a Traditional myth-symbol complex grounded in esoteric theology and Orthodoxy, Dugin is attempting to create a new identity for the Russian nation based on Traditional, not ethnic criteria.

Taken as a whole, Dugin's blueprint for a Eurasian empire could lead to nothing but enormous amounts of strife and bloodshed as the map is redrawn and empires are carved out. It is a fundamental manifestation of an apocalyptic worldview that sees an inevitable armed conflict between two spiritual forces, one represented by Western mercantilism, individualism

\footnotetext{
${ }^{125}$ Dunlop, Alexander Dugin's Foundations of Geopolitics, $<$ http://www.4pt.su/en/content/aleksandrdugin $\% \mathrm{E} 2 \% 80 \% 99 \mathrm{~s}$-foundations-geopolitics $>$

${ }^{126}$ Heiser, 61 .

${ }^{127}$ Heiser, 61.

${ }^{128}$ Heiser, 62.
} 
and rationalism and the other by Eastern spirituality, rootedness, and organic community. Thus, while Dugin's Foundations of Geopolitics is a cynical and dangerous manifesto, it is also a representation of his own mystical Traditional worldview embodied by how he and other Traditionalists have understood the sacral nature of geography.

In Traditionalism and other esoteric belief systems, geography has often conveyed important symbolic and spiritual meanings. Accordingly, the location of a space often bore a transcendent essence that manifested itself in the land's occupants. Julius Evola in particular articulated a vision of history according to sacred space. Indeed, it is Evola's ideas and their espousal by Alexander Dugin that have caused scholars such as Laruelle to see a racist component in Dugin's body of thought. Evola applied similar ideas similar to those of the vehemently racist and anti-Semitic Ariosophists of the interwar period in Germany. Typified by individuals such as Guido von List and Lanz von Liebenfels, Ariosophists combined esoteric mysticism and racism to articulate their version of world history. In brief, many Ariosophists believed, in some way or another, in the divinity of Aryan man and that the Aryan people had recently been subjected to racial miscegenation and moral decay through the advent of effeminizing democracy. ${ }^{129}$ Many of them believed that the Aryan people originated in lands to the far north, sometimes called Thule or Hyperborea. Before being poisoned by modern democracy, the Aryans had brought culture to the world and a natural order based on racial castes. $^{130}$

Evola maintained that during a remote prehistoric golden age, a great northern Arctic homeland of wise people had once existed known as Hyperborea. A "spiritual disaster" led to a major tilt in the Earth's axis, which forced the Hyperborean people to flee. They left for North America and northern Siberia, and later to a now lost continent of Atlantis in the middle of the

${ }^{129}$ Goodrick-Clarke, The Occult Roots of Nazism, 157.

${ }^{130}$ Goodrick-Clarke, The Occult Roots of Nazism, 157. 
Atlantic Ocean, eventually spreading to South America and places in Africa, and Asia; thus peoples who carried on a "Northern" spirituality existed all around the globe. A key aspect of Evola's Traditionalist thought was his conception of "Northern" and "Southern" spiritual features in the various peoples of the world. "Northern" peoples tended to embody a religious, masculine and Traditional understanding of nature. Conversely, "Southern" spirituality, associated with the moon and femininity, was largely decadent, materialistic and democratic. ${ }^{131}$ However, this was not an entirely ethnic distinction; "Southern" peoples could embrace a "Northern" spirituality and vice versa.

Dugin has also utilized the image of Hyperborea in his writings. His publishing house, Arctogaia is named after a mythic Arctic continent inspired by the imagery of the interwar Ariosophists. ${ }^{132}$ However, like Evola, he analyzes the Hyperborean myth through a Traditionalist viewpoint. Nevertheless Dugin has also argued for a spiritual understanding of geography. He maintains that ultimately the secrets of the universe can be unlocked by engaging in Traditional sciences. In his essay From Sacred Geography to Geopolitics, Dugin describes his geopolitical "science" as a necessarily modern rendition of a Traditional science, sacred geography. Just as alchemy, a sacred art used in Traditional rituals, has become desacralized through chemistry, so too has modern geopolitics become a profane study that does not grasp the essential spiritual struggle that exists in the modern world. ${ }^{133} \mathrm{He}$ characterizes this struggle as an ancient struggle between the Thalassocracy and Tellurocracy. The former, according to Dugin, can be identified today by its practice of a "southern" spirituality. It is exemplified by modern liberalism, rationalism, individualism, consumerism and metropolitanism, and is embodied by the United States and its allies. Conversely, the Tellurocracy can be identified by its rootedness, spirituality and religion, community, and

${ }^{131}$ Nicholas Goodrick-Clarke, Black Sun, chapter 3, Ebook.

132 Heiser, 53.

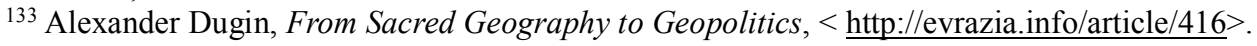


hierarchy and is embodied by most of the Eurasian peoples, in particular the Russians who are heirs to the spiritual truths passed down from Hyperborea. ${ }^{134}$ The sacred meaning of the cardinal direction of where a civilization is located also helps determine its character. As the United States is Western, it is a "country of death" in which the sun, symbolic of Perennial Tradition, goes to set. ${ }^{135}$ On the other hand, the East is "the Land of the Spirit," an "Eden" where the sun ascends. ${ }^{136}$

Alexander Dugin's beliefs about sacred geography and lost continents are truly bizarre. However, they are a manifestation of how deeply embedded his belief in the Perennial Tradition is. While Laruelle is correct to point out that Evola and Dugin both use a similar type of narrative to that of the Ariosophists, it is important to remember that Dugin and Evola approach the idea of Hyperborea through a specifically spiritual, not biological, prism. As Nicholas Goodrick points out, “Evola tended to see 'spirituality' as the prior determinant of a culture rather than its ethnic, racial population." 137 Thus, when Evola speaks of Hyperborea he is appraising it as a prehistorical font of spiritual wisdom and Tradition, not the homeland of a biologically superior race. In the same vein, Dugin uses the idea of Hyperborea in his mythsymbol complex not to denote Russia and its "Northern-ness" as the Aryan heirs to racial supermen, but rather as the heirs to a primordial Perennial Tradition.

For this reason Dugin has repeatedly come under attack by contemporary New Rightists and American white nationalists who have hitherto seen Dugin as a racial ally against multiculturalism, liberalism, and globalization. Contrary to some New Rightists who are simultaneously avowed Traditionalists and racists, Dugin has repeatedly argued against biological race as a meaningful factor in understanding culture, politics or history. The contemporary New Right is not a monolith. Rather, it is a conglomeration of groups and

\footnotetext{
${ }^{134}$ Dugin, From Sacred Geography to Geopolitics, < http://evrazia.info/article/416>.

135 Dugin, From Sacred Geography to Geopolitics, < http://evrazia.info/article/416 $>$.

${ }^{136}$ Dugin, From Sacred Geography to Geopolitics, < $\underline{\text { http://evrazia.info/article/416 }}>$.

${ }^{137}$ Goodrick-Clarke, Black Sun, Chapter 3. Ebook.
} 
individual thinkers who engage in a Gramscian strategy of metapolitics. They generally agree on an anti-American, anti-egalitarian, and anti-materialist outlook on the world. Furthermore, they propose an "Identitarian" project aimed at protecting individual ethnic cultures from cultural homogenization. ${ }^{138}$ Yet the movement is rife with internal conflicts, ranging from how they should adjust their metapolitical strategy over time to what the world would look like if the New Right actually gained the cultural hegemony it pursues. Furthermore, the New Right can largely be considered racist, or in the very least as a philosophy that believes race is a biologically important, even supreme, factor in understanding human society. However, recently some thinkers, including Benoist himself, have come under fire for doctrinal impurity, particularly by American New Rightists. Furthermore, by discussing the debates present within New Right discourse, we can more fully grasp Dugin's own stance on race by examining the criticisms levelled at him by open biological racists.

${ }^{138}$ Alain de Benoist and Charles Champetier, "Manifesto For a European Renaissance," appendix II in Against Democracy and Equality (London: Arktos, 2011), 228. 


\section{Chapter 4: Dugin, Race and the Racist New Right}

In New Culture, New Right the White Nationalist Michael O'Meara decries what he considers to be a blatant step backwards in the movement's metapolitical struggle. Up until 1998, GRECE emphatically opposed any attempts by the authorities to confer legal status to North African immigrants as a separate legal category on the grounds that this action would threaten France's identity. ${ }^{139}$ However, GRECE reversed course by adopting a more "communitarian" approach which favored the public recognition of non-French communities in order to facilitate the survival of the non-French immigrants' culture. ${ }^{140}$ Thus, according to O'Meara, began a series of intellectual retreats in which the French Nouvelle Droite began to exchange its original attempts at gaining cultural hegemony by diluting its ideas in favor of a much humbler mission of simply "interpreting" the present. ${ }^{141}$ By not continuing with the call for the expulsion of the non-European immigrants, according to the more determined New Rightists, Benoist and GRECE essentially gave up much of their racial nationalism for a "communitarian qualified multiculturalism." 142

Correspondingly, Guillamme Faye wrote his book Why We Fight as a reaction to what he saw as the weakening resolve of GRECE. ${ }^{143}$ In the work, Faye rails against the "system friendly" intellectuals of the right who only claim to have the best interests of the white race in mind. ${ }^{144} \mathrm{He}$ goes on to argue that the contemporary decadence of the French government, which he characterizes as a "multi-racialist mafia," will lead to "genetic ruin" for all of Europe. ${ }^{145}$

\footnotetext{
${ }^{139}$ O’Meara, New Culture, New Right, 104.

${ }^{140}$ O'Meara, New Culture, New Right, 104.

${ }^{141}$ O'Meara, New Culture, New Right, 105.

${ }^{142}$ O’Meara, New Culture, New Right, 105.

${ }^{143}$ Guillame Faye, Why We Fight: Manifesto of the European Resistance, trans. Michael O'Meara (London: Arktos, 2011), 12.

${ }^{144}$ Faye, Why We Fight, 12.

${ }^{145}$ Faye, Why We Fight, 20.
} 
Despite Dugin's protestations of good faith towards similarly-minded New Rightists, others within the movement do not consider him a member. In an interview with Open Revolt, Dugin argued that while he accepts White Nationalists only as common short-term allies against unipolarity and liberalism, he recognizes differences of opinion with them:

"More than this, I can't defend Whites when they are in opposition to non-Whites because, being White and Indo-European myself, I recognize the differences of other ethnic groups as being a natural thing, and do not believe in any hierarchy among peoples, because there is not and cannot be any common, universal measure by which to measure and compare the various forms of ethnic societies or their value systems." 146

In the article, "The Magic Disillusion of a Nationalist Intellectual," Dugin talks about what he calls the "myth of the solidarity of a single white race." ${ }^{147}$ In it he described the belief in a single, unitary white or Aryan race as a "utopia that could only lead to the Holocaust of the Jews..." as well as the Slavs. ${ }^{148}$ He continues,

"The remains of the Third Reich are a basis for this miserable, contradictory and completely false conception. The Anglo-Saxon world is one sociopolitical and cultural reality. The inhabitants of Central Europe are something different. The Eastern world of Orthodox Christianity and Slavs is a third reality. I am certain that many non-white peoples of Eurasia are a thousandfold closer to us in spirit and culture than Americans. In this question I am 100\% affirmative with the visions of [Lev] Gumilev."149

With this statement Dugin not only asserts that race is not a meaningful factor in categorizing

\footnotetext{
146 “Alexander Dugin on 'White Nationalism' and Other Potential Allies in the Global Revolution," Open Revolt!, $<$ http://openrevolt.info/2013/05/19/alexander-dugin-on-white-nationalism-and-other-potential-allies-inthe-global-revolution/>

$\frac{147}{14 b i d .}$

${ }^{148}$ Ibid.

${ }^{149}$ Ibid.
} 
peoples but also proposes an ethno-cultural interpretation of Gumilev's theories, rather than a biological one. Yet again, Dugin attacked race as a defining factor in national identity during a lecture in which he characterized race as a "social construct." ${ }^{150}$ Dugin has also called for the end of "chauvinism, Eurocentrism, universalism, racism, [and] xenophobia... ${ }^{151}$ Despite his protestations against racism, he nonetheless considers himself an ally to the New Right and believes that the New Right à la Benoist is more or less consistent with his own fourth political theory. ${ }^{152}$

Dugin's declarations that race is an unimportant or even non-existent factor when assessing identity has proven troublesome for many other New Rightists. For some this may be linked in Dugin's overt links to Traditionalism. It is of course true that Traditionalism and Julius Evola have been an important intellectual inspiration for racist thinkers. The recently deceased Jonathan Bowden, a self-described Nietzschean, in a talk hosted by members of the New Right in London on June 5, 2010 lectured on the importance of Evola's thought on the contemporary New Right. ${ }^{153}$ Bowden argues that Evola and Tradition have been instrumental in infusing the New Right with a spiritual and intellectual backbone that has allowed the New Right to "ride the tiger" of modernity. ${ }^{154}$ However, Bowden warns that Traditionalism, placed in the wrong hands, could lead to a dangerous “...sort of universalism at times or a neoliberalism occasionally where all cultures are of value, where all are 'interesting,' where all are slightly interchangeable." 155 In other words, Bowden warns that Traditionalism has the potential to be read as a pro-multicultural worldview. In a similar fashion, Guillame Faye, an

\footnotetext{
${ }^{150}$ Alexander Dugin, “Alexander Dugin (Introduction by Mark Sleboda) Identitär Idé 4 / Identitarian Ideas 4” Youtube Video, posted by Tankesmedjan Motpol September 12, 2012, https://www.youtube.com/watch?v=7X-o ndhSVA. ${ }^{151}$ Dugin, Putin vs Putin, 310.

152 Dugin, Putin vs Putin, 310.

${ }^{153}$ Jonathan Bowden, "Jonathan Bowden - Julius Evola: The World's Most Right-Wing Thinker" Youtube Video, posted by TheArmenianNation June 11, 2013, https://www.youtube.com/watch?v=4YqKf3v2aPs.

154 "Ride the tiger" is the tile of one of Julius Evola's later works in which, having given up on affecting any real change in modern spiritual decadence, he instead discusses how one who is Traditionally-minded could cope with living in modern times. Ibid.

155 Jonathan Bowden, "Jonathan Bowden - Julius Evola, Youtube Video.
} 
avowed reader of Evola, also warned against Tradition. Faye urges caution against "Evolianism," which taken too far, "turns away from practical, tangible issues," presumably the Identitarian struggle. ${ }^{156}$

Various authors of the New Right have directly targeted Dugin as an enemy of the movement over the subject of race. The online webzine Counter-Currents has been a gathering place of mostly Anglophone New Rightists to publish articles about race, culture, politics, and religion since 2010. Headed by its editor-in-chief, Greg Johnson, Counter-Currents describes itself as having taken its intellectual cues from the anti-modernism of René Guénon and the ethnic and racial nationalism of the European New Right. ${ }^{157}$ Counter-Currents and similar North American New Right metapolitical organs have provided mouthpieces to New Right intellectuals who claim Dugin is not truly an ally of theirs or is at least only minimally connected to the broader New Right ideology.

In the article "Dugin Contra Racism," Giuliano Adriano Malvicini maintains that Dugin is not a racist but a postmodern moral relativist. Malvicini complains that Dugin's "incessant denunciations of racism" are aimed purely at the West without regard to the racism present in other parts of the world. ${ }^{158}$ Additionally, Malvicini argues that Dugin's arguments against National Socialism in his The Fourth Political Theory are fundamentally flawed as he accepts the dominant, and (Malvicini maintains) wrong, liberal narrative that German National Socialism was fundamentally against other races. Absurdly, Malvicini says, National Socialism was simply pro-German. ${ }^{159}$

Some New Rightists have changed their opinion of Dugin and his ideas over time. In 2004, Michael O'Meara described Dugin as a "Russian Identitarian" who shared the same

156 Guillame Faye, Why We Fight, 32.

157 “About Counter-Currents Publishing and the North American New Right," Counter-Currents, $<$ http://www.counter-currents.com/north-american-new-right/ $>$.

158 Giuliano Adriano Malvicini, "Dugin Contra Racism," Counter-Currents, September, 2014, $<$ http://www.counter-currents.com/2014/09/dugin-contra-racism/>.

${ }^{159}$ Malvicini, "Dugin Contra Racism," Counter-Currents. 
worldview as himself. ${ }^{160}$ However, in an article written in 2013, O’Meara presents Dugin as a thinker who is "difficult to pigeonhole" but nonetheless antithetical to the New Right project. Despite the anti-egalitarianist and anti-materialist spirit of much of Dugin's work, O'Meara is completely against Dugin's Eurasian geopolitical goals and what they seem to represent multi-culturualism. ${ }^{161}$ O'Meara argues that, despite Dugin's claims that a Eurasian empire under Russia would protect the individual cultures of various ethnic groups, O’Meara contends that this ethnopluralism would only lead to another, slightly more localized "anti-cultural" form of multi-culturalism in which Jews, Muslims, Turks, Mongols, and Slavs would live together. ${ }^{162}$ Thus Dugin's Eurasianist project is not unlike the communitarian concessions made by Benoist over immigration. Indeed, O'Meara goes so far to argue that the likes of Benoist and Dugin and their "miscegenating principles of global cosmopolitanism," are dangerous to both the New Right and Europe. ${ }^{163}$ According to thinkers like O’Meara, Dugin's Eurasianism "mixes white and yellow" and is anathema to any ethno-nationalist project. ${ }^{164}$

Greg Johnson has also come out to attack Alexander Dugin's writings. Contrary to many other New Rightists who hope for the economic as well as political unification into a more or less federalized white Europe, Johnson anticipates that a victorious New Right will oversee the creation of dozens of smaller states. These white ethno-states, determined by plebiscite, would be based on ethnic, cultural, and religious factors. ${ }^{165} \mathrm{He}$ describes Dugin's Neo-Eurasianist project as fundamentally against smaller, white, nationalities. Instead, Johnson views it as more or less a ploy to resurrect the Soviet Union in territory, if not necessarily in its constitutive spirit. ${ }^{166}$ Similarly, according to Johnson, Dugin's call for multi-polarity is just

\footnotetext{
${ }^{160}$ O’Meara, New Culture, New Right, 110.

${ }^{161}$ Michael O'Meara, “The Third Political Theory” Counter-Currents, April, 2013, < $\underline{\text { http://www.counter- }}$ currents.com/2013/04/the-third-political-theory/>.

162 O'Meara, "The Third Political Theory" Counter-Currents.

163 O'Meara, "The Third Political Theory," Counter-Currents.

${ }^{164}$ O’Meara, “The Third Political Theory,” Counter-Currents.

${ }^{165}$ Greg Johnson, Old Right vs. New Right (San Francisco: Counter-Currents Publishing ltd., 2013), Ebook.

${ }^{166}$ Greg Johnson, "Americanism: A Cautionary Tale," Counter-Currents, November, 2013,

$<$ http://www.counter-currents.com/2013/11/north-americanism-a-cautionary-tale/ $>$.
} 
another form of hegemony, leading, if successful, to the creation of a multi-racial empire that is more concerned with state power than advancing ethnic, that is, white, concerns.

Although the New Right has not proposed a united, very specific geopolitical project, some have suggested plans like that of Greg Johnson, in which Europeans and EuropeanAmericans form small, ethnically and culturally homogenous states that rely on the larger countries such as France or the United Kingdom with nuclear deterrents to protect the smaller white states. ${ }^{167}$ Other, perhaps the majority, foresee the formation of a somewhat loosely administered but united European empire. Guillaume Faye, for instance, calls for the formation of an all-white empire of "Euro-Siberia" that would stretch from Iceland to Siberia. ${ }^{168}$ Yet Alexander Dugin's Neo-Eurasianist project seems to fly in the face of these members of the New Right. Contrary to any all-white supranational project proposed by other New Rightists, Dugin's Neo-Eurasian empire would include the direct annexation of Mongolia into Russia proper. Furthermore, Eurasia's expansion into northern and western China would certainly lead to a larger non-European Chinese and Central Asian population within Russia. In addition, in exchange for the territorial enlargement of Dugin's Eurasia at the expense of China, China would be granted suzerainty over the majority white country of Australia. ${ }^{169}$ Given Dugin's open discussion on how he envisions a Eurasian empire, it is not likely that he has the goal of creating a racially homogenous community of nations in mind. Rather, it seems far more likely that Dugin truly does not see biological race as a meaningful constitutive part of any form of identity. Indeed, as this study has demonstrated, the overt lack of racism in Dugin's thinking has caused some within the New Right to question his presence in the movement altogether.

\footnotetext{
${ }^{167}$ Greg Johnson, “Grandiose Nationalism,” Counter-Currents, February, 2015, $<\underline{\text { http://www.counter-currents.com/2015/02/grandiose-nationalism/ }>}$

168 Faye, Why We Fight, 141.

${ }^{169}$ Dugin, Foundations of Geopolitics, <http://www.my.arcto.ru/public/osnovygeo/>, Ch. 4.
} 


\section{Chapter 5: Dugin and Fascism}

As this study has demonstrated, Dugin's Neo-Eurasianist project cannot be premised upon a belief in biological race. Considering this, it is now important to investigate whether or not Dugin can be considered a fascist. Fascism has long been a highly contested term and has been the subject of much scholarly debate. Fascism is a disputed topic because unlike communism or liberalism, which has had time to develop intellectual and theoretical backdrops to their respective broad ideologies, fascism as a form of government existed in practice for a very short period of time during the interwar years. Indeed, some would go so far as to say that fascism, unlike liberalism or communism, inherently lacked any major essential intellectual foundations as it was a fundamentally emotive and reactive political movement that emphasized action over philosophy. Furthermore, many fascist experiments throughout the history of the broad movement exhibited different tendencies. For instance, Nazi Germany exhibited an extreme biological racism and anti-Semitism while Fascist Italy largely viewed race, or la Razza, as a cultural rather than biological phenomenon and only belatedly and in slavish emulation of Nazi Germany enacted anti-Semitic laws. ${ }^{170}$ Similarly, Nazi Germany was perhaps the most "perfected" form of fascism in which traditional elites were almost completely deposed and Nazism permeated almost all of German daily life. Conversely, Fascist Italy was only partially successful in implementing a fascist program. Mussolini had to contend not only with a sometimes recalcitrant Catholic Church but even with the persistence of the Italian monarchy until Mussolini’s dismissal from office.

According to the historian Robert O. Paxton, fascism, unlike communism in which internationalism is more or less a facet of its foundational philosophy, emphasizes a nation's “cultural particularism" which precludes it from a simple taxonomy. ${ }^{171}$ Some scholars, such as

\footnotetext{
${ }^{170}$ Robert O Paxton, The Anatomy of Fascism (New York: Vintage Books, 2004), Ebook.

${ }^{171}$ Paxton, Anatomy, Ebook.
} 
Zeev Sternhell, have essentially given up on using the term "fascism" outside of the context of Mussolini's Italy. ${ }^{172}$ For instance Sternhell contends that the centrality of biological racism in National Socialism and the lack of it in Italian Fascism precludes them from being classified as representatives of a generic fascism. ${ }^{173}$ Rather, would-be fascisms such as Romania's Iron Guard movement and the Spanish Falangists should be understood as unique phenomena unto themselves. On the other hand, other scholars including Roger Griffin, Stanley G. Payne and Robert O. Paxton hold that the problem of a generic fascist definition is not an insurmountable one. They have attempted to establish a "fascist minimum," a set of criteria that, if met by the investigated political group, would allow scholars to identify them as a genuinely fascist movement. Griffin has argued that a subject ideology meets the fascist minimum if it "...is a political ideology whose mythic core in its various permutations is a palingenetic form of populist ultra-nationalism." ${ }^{174}$ In other words, an ideology can be considered fascist when it combines a profound belief in the national need for a restoration of sacred values in order to be born anew with an extreme, often messianic and expansionist, nationalism. For the purposes of this study Griffin's “fascist minimum” will be the means of measuring Neo-Eurasianism's fascist potential. However, prior to discussing Alexander Dugin's possible fascism it is essential to discuss more in depth the historiographical and scholarly debate surrounding fascism in order to place Dugin's body of thought within the broader context of the debate.

Marxist thought has contributed significantly to the debate over fascism. It is no surprise that Marxist ideologues and scholars both have proposed an understanding of fascism that emphasizes class warfare. Marxist historians such as Dave Renton have repeatedly criticized other historians for their lack of emphasis of fascism's fundamentally capitalist and anti-labor

\footnotetext{
172 Zeev Sternhell trans. David Maisel The Birth of Fascist Ideology: From Cultural Rebellion To Political Revolution (Princeton: Princeton University, 1994), 5.

173 Sternhell, The Birth of Fascist Ideology, 5.

${ }^{174}$ Roger Griffin, The Palingenetic Core of Fascist Ideology, $<$ https://www.libraryofsocialscience.com/ideologies/docs/the-palingenetic-core-of-generic-fascistideology/index.html $>$.
} 
character. ${ }^{175}$ Marxist historiography argues that fascist experiments such as in Italy and Germany were in large part a violent reaction of capitalism against the proletariat in order to preempt an increasingly possible communist revolution. ${ }^{176}$ This is not to say that fascist movements were necessarily created by the ruling capitalists. Yet, Marxists maintain, fascism cannot come into power or remain in it without the support and funding of capitalists and big businesses. Once in power, fascist movements largely act to the benefit of industrialists or business owners by implementing reactionary laws aimed at restoring hierarchy, curtailing the ability of workers to organize, and violently suppressing all those who oppose them. ${ }^{177}$ In a similar vein, the historian Ernst Nolte, although not a Marxist, nonetheless came to the a parallel conclusion to that of Marxists by arguing that Fascism represented not so much a collection of positive ideas but a collection of negations the first two being anti-Marxism and anti-materialism. ${ }^{178}$ According to Nolte, the Jews represented to Hitler and the Nazis a physical manifestation of a "spirit of modernity" whose values including Marxism, consumerism, and rationalism led to total cultural decadence and ennui. ${ }^{179}$ Thus the Holocaust enacted by the Nazis represented a penultimate war against modernity and its values.

While Marxists and other scholars see a continuation of class warfare or violent antimodernism in historical fascism, others view it as a still more complicated phenomenon. The historian Emilio Gentile argues that a fascist movement is constituted by a broader appeal to not only anti-Marxism but also anti-capitalism and anti-modernism and its supporters have historically come from throughout the economic spectrum. The following lists Gentile's understanding of what a fascist movement is:

1. a mass movement with multiclass membership in which prevail, among the leaders and the militants, the middle sectors, in large part new to political activity, organized as a party militia, that bases its identity not on social hierarchy or class origin but on a sense

\footnotetext{
${ }^{175}$ Dave Renton, Fascism: Theory and Practice (London: Pluto Press, 1999), 12.

176 Renton, Fascism, 30.

177 The Encyclopedia of Marxism < https://www.marxists.org/encyclopedia/terms/f/a.htm\#fascism>.

${ }^{178}$ Ernst Nolte, The Three Faces of Fascism (London: Weidenfeld and Nicolson, 1965), 20-21.

${ }^{179}$ Ibid., 31.
} 
of comradeship, believes itself invested with a mission of national regeneration, considers itself in a state of war against political adversaries and aims at conquering a monopoly of political power by using terror, parliamentary politics, and deals with leading groups, to create a new regime that destroys parliamentary democracy;

2. an 'anti-ideological' and pragmatic ideology that proclaims itself antimaterialist, antiindividualist, antiliberal, antidemocratic, anti-Marxist, is populist and anticapitalist in tendency, expresses itself aesthetically more than theoretically by means of a new political style and by myths, rites, and symbols as a lay religion designed to acculturate, socialize, and integrate the faith of the masses with the goal of creating a 'new man';

3. a culture founded on mystical thought and the tragic and activist sense of life conceived of as the manifestation of the will to power, on the myth of youth as artificer of history, and on the exaltation of the militarization of politics as the model of life and collective activity;

4. a totalitarian conception of the primacy of politics, conceived of as an integrating experience to carry out the fusion of the individual and the masses in the organic and mystical unity of the nation as an ethnic and moral community, adopting measures of discrimination and persecution against those considered to be outside this community either as enemies of the regime or members of races considered to be inferior or otherwise dangerous for the integrity of the nation;

5. a civil ethic founded on total dedication to the national community, on discipline, virility, comradeship, and the warrior spirit;

6. a single state party that has the task of providing for the armed defense of the regime, selecting its directing cadres, and organizing the masses within the state in a process of permanent mobilization of emotion and faith;

7. a police apparatus that prevents, controls, and represses dissidence and opposition, even by using organized terror;

8. a political system organized by hierarchy of functions named from the top and crowned by the figure of the 'leader,' invested with a sacred charisma, who commands, directs, and coordinates the activities of the party and the regime;

9. corporative organization of the economy that suppresses trade union liberty, broadens the sphere of state intervention, and seeks to achieve, by principles of technocracy and solidarity, the collaboration of the 'productive sectors' under control of the regime, to achieve its goals of power, yet preserving private property and class divisions;

10. a foreign policy inspired by the myth of national power and greatness, with the goal of imperialist expansion. ${ }^{180}$

Thus Gentile outlines an understanding of fascism as a multi-faceted ideology that is typified not just by a collection of shared negative values. For Gentile, fascism is also a series of positive values including not only extreme nationalism and a vision of national rejuvenation but also a

${ }^{180}$ Quoted in Stanley G. Payne, A History of Fascism 1914-1945 (Madison: The University of Wisconsin Press, 1995), 5-6. 
devotion to authoritarian or totalitarian hierarchy, the primacy of politics over economics and the collective over the individual, as well as a cult of violence and militarism.

Gentile's understanding of what constitutes a typical fascist state or ideology is one that can generally be accepted by most scholars. However, a critical point of conflict in our understanding of fascism is its stance on modernity. Just as fascists have historically compromised with conservative elites, if sometimes only temporarily, so too have fascists "compromised" with modernity. Stanley G. Payne's outline of a definition of fascism emphasizes the paradoxically modern and anti-modern nature of fascist ideologies:

"1. Ideology and Goals:

- Espousal of an idealist, vitalist, and voluntaristic philosophy, normally involving the attempt to realize a new modern, self-determined, and secular culture

- Creation of a new nationalist authoritarian state not based on traditional principles or models

- Organization of a new highly regulated, multiclass, integrated national economic structure, whether called national corporatist, national socialist, or national syndicalist

- Positive evaluation and use of, or willingness to use violence and war

- The goal of empire, expansion, or a radical change in the nation's relationship with other powers

2. The Fascist Negations:

- Antiliberalism

- Anticommunism

- Anticonservatism (though with the understanding that fascist groups were willing to undertake temporary alliances with other sectors, more commonly with the right)

3. Style and Organization:

- Attempted mass mobilization with militarization of political relationships and style and with the goal of a mass single party militia

- Emphasis on aesthetic structure of meetings, symbols, and political liturgy, stressing emotional and mystical aspects

- Extreme stress on the masculine principle and male dominance, while espousing a strongly organic view of society

- Exaltation of youth above other phases of life, emphasizing the conflict of the generations, at least in effecting the initial political transformation

- Specific tendency toward an authoritarian, charismatic, personal style of command, whether or not the command is to some degree initially elective." 181

${ }^{181}$ Payne, A History of Fascism, 7. 
Payne argues that fascism, while rejecting many modern values such as materialism, rationalism, the primacy of economics in understanding human relations, and human rights, nonetheless demonstrates its own modern nature through secularization, the displacement of traditional elites, populism, and the further bureaucratization of the state. Indeed, other scholars have pointed out the modern nature of fascism in not only its administrative actions but also in its aesthetics and worldview. While despairing of contemporary bourgeois values, fascists rarely took inspiration from idealized values within the past. Rather, fascists often attempted to create a new, modern value system that highlighted the powerful and violent capabilities of modern technology and the efficiency of industry. ${ }^{182}$ For instance, in Italy Tommaso Emilio Marinetti an early supporter of Fascism, called for a rejection of what he saw of bourgeois decadence and prudery. In its place, Marinetti envisioned a new, palingenetic society in which technology facilitated the growth a militant and zealous cult of the nation. ${ }^{183}$ Akin to Marinetti, Ernst Jünger called for the creation of a modern "warrior-worker." ${ }^{184}$ This new class of man would zealously work toward an advanced industrial society which would be totally mobilized towards the needs of the nation and willing to fight at a moment's notice.

In summation, we can understand a movement or ideology to be fascist at the bare minimum when a palingenetic ideology of national rebirth meets ultranationalism. We can also distill other scholars' interpretations of fascism to generalize that typical forms of fascism have often displayed a zealous militarism, expansionism, populism, authoritarianism and modernism while maintaining a hostility towards liberalism, Marxism, rationalism, and bourgeois values. At the same time however, fascism, while calling for a rebirth of the nation, often envisions a completely new nation rather than a restored idealized past. Thus fascist states tend to

\footnotetext{
182 Jobst Welge ed. Astradur Eysteinsson and Vivian Liska "Fascist Modernism" Modernism, Vol. 2. (Philadelphia: John Benjamins Publishing, 2007), 550.

${ }^{183}$ Welge, "Fascist Modernism," 550.

${ }^{184}$ Welge, "Fascist Modernism," 553.
} 
emphasize a new modern aesthetic of technology, efficiency, apocalyptic violence and a new hierarchy that is ultimately largely disdainful of tradition.

Robert Paxton has raised the important point that fascist ideological programs, insofar as they had ones, prior to coming to power did not always coincide with their policies once they did come to power. ${ }^{185}$ It would be, for example, a problematic methodology to attempt to understand Nazism largely through reading the early Nazi speeches, particularly of the Strasser brothers. ${ }^{186}$ Yet Dugin is not in power, nor does Vladimir Putin openly support Dugin's worldview. Thus in ascertaining whether or not Dugin's Neo-Eurasianism meets a fascist minimum his body of written ideas are largely the only sources on which to draw from.

It is initially self-evident that Alexander Dugin's body of thought certainly represents, in the least, fascistic tendencies. After all Dugin is a vehement opponent of liberalism, egalitarianism and consumerism. He has repeatedly supported Vladimir Putin and his repressive tactics in the hopes that Putin will lay the foundation for an internationally resurgent Russia. It has also been thoroughly demonstrated that Dugin is anything but a pacifist and is very willing to engage in war, particularly with the United States, if it leads to the formation of a Eurasian empire. Dugin's plans for imperial expansion positively dwarf even the most ambitious plans of Nazi expansion and Lebensraum. Indeed, Dugin's hatred of what he sees as the morally decaying effects of American hegemony matches closely with Nazism's obsessive hatred of Jews and their paranoia over Jewish and Bolshevik infiltration.

Yet in applying Griffin's fascist minimum to Dugin's case it can only be concluded that Neo-Eurasianism, while certainly sharing many traits with historical cases of fascism, is not necessarily a fascist doctrine. As this work has demonstrated, Dugin, like many fascists, yearns

\footnotetext{
185 Paxton, Anatomy, Ebook.

${ }^{186}$ Gregor and Otto Strasser were early members of the NSDAP who functioned as the leaders of the left wing of the party. They underscored a virulent anti-capitalism and socialist program that simply did not ultimately represent Nazism in practice. Rather, both brothers and their followers represented a threat to Hitler's control over the party and Otto was expelled from the party in 1930 while Gregor was killed in 1934 during the Night of the Long Knives.
} 
for a complete reconstruction of state, culture and society. However, while fascism has ultimately emphasized a fundamentally alternative modern vision of a new state, Dugin's worldview, characterized as it is by Evola and Tradition, is utterly anti-modern. Fascist Italy and Nazi Germany were both characterized by a fondness for industry, efficiency and bureaucracy. The reigning aesthetic was one that emphasized youth, vigor, productivity and technological progress. Conversely, Dugin is deeply ambivalent toward any narrative of progress and even modern technology.

In his The Fourth Political Theory Dugin describes an isolated community of Old Believers who live in the Ural Mountains. Here, these "fundamental conservatives" avoid seemingly trivial affectations such as wearing plaid. ${ }^{187}$ In addition, they only use torches and candles for lighting for electrical lighting is "'the light of Lucifer." 188 They also scorn the eating of boiled buckwheat or the drinking of tea and coffee as "'sinful."”189 Dugin urges the reader not to consider these practices outdated or odd, but rather understand that their antagonism toward modern values is so complete that they will also spurn the use of modernity's concomitant technological marvels. For these Old Believers rightly see that “...time is regress, and modern men are a sacrificial offering to the devil." ${ }^{190}$ For Dugin, then, it is completely acceptable and even desirable to not only reject modernity and any narrative of progress but to even participate in traditionalist religious communities that enforce this worldview. Dugin's anti-modernism is anathema to fascism's vitalist cult of technology and action which, while against certain aspects of modernity such as what they would describe as consumerism, hedonism and individualism, nonetheless allowed for an alternative vision of modernity which allowed technological and social innovation. On the contrary, Dugin's antimodernism seems to be a holistic critique of any form of modernism that allows for any

\footnotetext{
${ }^{187}$ Dugin, Fourth Political Theory, 90.

${ }^{188}$ Dugin, Fourth Political Theory, 90.

${ }^{189}$ Dugin, Fourth Political Theory, 90.

${ }^{190}$ Dugin, Fourth Political Theory, 90.
} 
narrative of progress, social and/or technological, that would lead man further away from Tradition. Thus while both fascism and Neo-Eurasianism can be said to be palingenetic, the former desires an alternative modernity, while the latter completely rejects modernity in all its forms.

In regards to the second criteria of Griffin's fascist minimum, ultranationalism, Dugin's approach to nation is complex. As has been demonstrated, Dugin clearly desires Russia to create a massive empire that would exceed the territorial extent of the Soviet Union. However, just as Traditionalism has colored Dugin's understanding of modernity, so too has it influenced his understanding of nation. While Italian fascism viewed la Razza in largely cultural terms, Italian Fascism nonetheless took for granted the fact that Italians were to be the main beneficiaries of a fascist state. Indeed, while Italian Fascism was not explicitly racist in its doctrine, this did not stop Fascist Italy from deporting Slovenes to a concentration camp on the island of Rab nor exacting even harsher revenge against recalcitrant African natives. ${ }^{191}$ Even more explicitly than fascism in Italy, German National Socialism viewed the welfare of the German nation as the penultimate goal to strive toward. No other nation, particularly Jews, were permitted to block Germany's national destiny to become a continental hegemon. In short, fascist thought argues that one's nation and the state ruling and administering that nation represent the highest value.

In opposition, Dugin proposes an understanding of the Russian nation that allows for its importance but only insofar as it is a spiritual liberator of Eurasia and the fomenter of a greater identity. Indeed, like the European New Right which proposes a new, supranational model of identity that transcends any extreme pride in a single nation, Neo-Eurasianism calls for the formation of a new geopolitical entity and identity. Concomitantly, Dugin's proposed

${ }^{191}$ Pamela Ballinger, History in Exile: Memory and Identity at the Borders of the Balkans (Princeton: Princeton University Press, 2003), 138. 
neo-Eurasian identity is one based on spirituality and Traditional thought. Dugin sees the Russian nation as a potential spark to unite Eurasian civilization into a greater empire that, after defeating the United States, will then attempt to return to Traditional hierarchy and value systems. For Dugin Traditional spirituality is the highest value. Given this, it is impossible to define Dugin as an ultranationalist like historical fascists.

In conclusion, Dugin does not wholly meet the criteria of a fascist minimum. This is not to say that Neo-Eurasianism represents any less of a dangerous ideology to international peace or liberal democracy. Dugin's philosophy certainly shares the "fascist negations" that include anti-egalitarianism, anti-democracy and anti-liberalism. Neo-Eurasianism also shares a similar palingenetic worldview to that of fascist movements. However, while fascism's national rebirth is an alternative form of modernity that emphasizes some aspects of modernity and discards others, Dugin's anti-modernity is profoundly reactionary. Correspondingly, while a central tenet of fascism is ultranationalism and extreme pride in a single nation, Dugin proposes a supranational project that would place the Russian nation along with numerous other peoples in a larger empire. Russia, in short, is an important facet of Dugin's project, but it is not an end in itself. 


\section{Conclusion}

As recently as October, 2014, Alexander Dugin was scheduled to participate in a conference in Budapest, Hungary hosted by the National Policy Institute, an American New Right think tank. Here Dugin, along with Greg Johnson and others of the New Right were planning on delivering talks and lectures on the state of the movement. However, in late September, the Hungarian government banned the conference from taking place. ${ }^{192}$ In response, Alexander Dugin instead posted a Youtube video of the lecture that he would have given, had the conference taken place. In the video, Dugin rehashes much of what he has already articulated in his theoretical works on the Fourth Political Theory. He argues that the New Right must reject all forms of racism, which he argues is an Anglo-Saxon creation and includes biological racism, eurocentrism and the "racist" universality of liberalism and Marxism. At the same time he maintained that there is not one universal humanity but a collection of various humanities defined by "civilization." 193 Thus Europe and Eurasia, based on different civilizational models, should remain allies to fight against their common enemy, the United States' global hegemony, but should respect one another's civilizational differences. Thus Dugin signaled once again that a collective civilizational and Traditional mythomoteur animates and gives meaning to national and supranational identities, not biological race or ethnicity.

Given his repeated declarations of anti-racism and a disbelief in biological race, it is curious that he seems to remain an accepted member of the New Right despite an increasing number of protests against him within the ranks. Part of this can be explained by the fact that, even if Dugin is not a racist, as many are now realizing, he still represents a popular anti-liberal

\footnotetext{
192 Sándor Pintér, "Minister of Interior Bans Racist Conference, Website of the Hungarian Government, September 29, 2014, <http://www.kormany.hu/en/ministry-of-interior/news/minister-of-interior-bans-racistconference>.
}

193 
academic within Russia whose views nonetheless share an anti-egalitarianism and antiAmericanism similar to that of the rest of the New Right. Concomitantly, a Eurasianist Russia, even if not sharing the biological racism shared by many within the New Right, would nonetheless constitute a powerful enemy against American global power.

It goes without saying that regardless of Dugin's stance on race, Neo-Eurasianism is a genuinely dangerous doctrine to world peace and is a threat to international stability. In February, $2014 \mathrm{Kiev}$, the capital city of Ukraine, was rocked by a series of increasingly violent clashes between protesters and government forces. The source of the conflict was over the refusal of Ukrainian president Viktor Yanukovych to sign a trade agreement with the European Union that would see Ukraine tied closer economically to Europe and decrease Russian economic influence in Ukraine. Instead, in December 2013 Yanukovych elected to sign a trade agreement with Russia, which included cheap natural gas from the Russian Federation to Ukraine in exchange for providing the Russian navy with warm water ports along the Kerch peninsula. ${ }^{194}$ Almost immediately pro-western Kievans began a series of protests against their government's decision. The protests, initially peaceful, quickly became violent as police forces sought to quell the unrest. With no end in sight to the rising tensions and violence, Yanukovych fled the country and a new interim government took control of the Ukrainian state. With the fall of the pro-Russian Ukrainian government and with the support of Putin's Russia, ethnically Russian areas of Ukraine, notably the Crimean peninsula and eastern parts of the country began violently agitating for independence. As we speak, there continues to be something akin to a civil war developing within Ukraine. The Crimean peninsula has been successfully annexed into the Russian Federation and areas with many ethnic Russians have been equipped and sometimes supported by Russian troops.

Despite President Vladimir Putin's repeated declarations that the Russian Federation

${ }^{194}$ Oksana Bashuk Hepburn. "Putin's Meddling in Ukraine Sinister.” Winnipeg Free Press, February 22, 2014. 
does not desire to get involved in a foreign country's internal affairs, it is an open secret that Russian troops have armed separatists in the Donetsk and Luhansk regions that have seized parts of Ukraine. Unsurprisingly, Russian ultranationalists such as Vladimir Zhirinovsky have openly called for even further encroachments upon Ukrainian sovereignty. Indeed, Zhirninovsky has gone so far as to threaten the "destruction" of Poland and the Baltic states if the United States and the rest of the West retaliated against Russia's intervention in Ukraine. ${ }^{195}$ Like Zhirinovsky, many nationalists view Ukraine, or at least significant parts of its territory, as part of Russia's legitimate territory. The foundation of a Ukrainian state in the aftermath of the breakup of the Soviet Union constituted a defeat for the Russian nation and a victory for the West, an eternal enemy in much of Russian nationalist discourse. Ukraine's loss is just one of many injustices that contemporary Russian nationalists hope to redress in their lifetimes - a hope that they have placed in the person of Vladimir Putin.

For the likes of the Russian philosopher and radical rightist Alexander Dugin, a successful outcome for Russia in Ukraine is hopefully just a small segment of a much larger geopolitical project. While Neo-Eurasianism and the Fourth Political Theory remain largely a part of fringe political discourse, it is not impossible that it will not gain traction with both elites and common Russian citizens in the future. As it stands, Dugin himself has remained ambivalent on measuring the amount of real impact his ideas have had on Russian politics. On one hand he has proudly pointed out the fact that his Foundations of Geopolitics remains a popular book for many Russian officers and policy makers. Dugin has gone so far to contend that his ideas have influenced Vladimir Putin. ${ }^{196}$ On the other hand, he has also claimed that Putin is ultimately a political pragmatist and has little time for ideology. ${ }^{197}$ Thus, while Dugin

\footnotetext{
${ }^{195}$ Catherine A. Fitzpatrick, "Russia This Week: Zhirinovsky Threatens to 'Wipe Out' Poland, Baltics." The Interpreter August 4, <http://www.interpretermag.com/russia-this-week-roots-of-pro-russian-separatists-inrussianultranationalistgroups/>.

${ }^{196}$ Dugin, Putin vs Putin, 27.

${ }^{197}$ Dugin, Putin vs Putin, 235.
} 
has repeatedly argued that Putin stands the best chance of successfully countering global American hegemony and creating a greater Russian empire, he also worries that Putin's pragmatism and lack of philosophical convictions will only lead Russia towards a slow but definite slide into liberal democracy. ${ }^{198}$ Given that Dugin's geopolitical and illiberal worldview virtually demands a global war against the United States and its allies, one can only hope that Dugin's fears come true.

This study has argued against interpreting Alexander Dugin's Neo-Eurasianism as a more or less ethnic or racist, fascist blueprint. Despite his membership within the New Right it is important to note that even its founder, Alain de Benoist, has come under attack for doctrinal impurities when it came to discussions of race and "white survival." One of the major problems with contemporary academic discussion of Dugin and the New Right is a tendency to characterize the project as something of a monolith rather than a deeply fragmented conglomeration of similar yet competing sub-ideologies. Dugin shares the anti-Americanism, anti-democratic and anti-liberal tendencies of the New Right. He, along with the New Right, are intellectual heirs of Traditional thought and the Conservative Revolution to one degree or another. Yet Dugin has repeatedly articulated a fundamentally different view of identity than the New Right and fascism.

Dugin has offered many protestations against biological racism. His geopolitical visions seem to discount race or ethnicity and elevate cultural, historical and spiritual factors in his Eurasian project. Furthermore he has espoused a Traditional worldview that discounts biological race. Dugin's worldview is colored by something else. His ideology is not grounded upon racial or ethnic notions of identity, despite his fascistic leanings. Rather, Dugin's ideology is grounded in the esoteric belief in a Perennial Tradition of which Orthodox Christianity and other Eurasian traditional religions represent facets of a single divine truth. Combining a myth-

${ }^{198}$ Dugin, Putin vs Putin, 289. 
symbol complex utilizing a mixture of Traditionalist belief in Russia's messianic need to unify and protect other peoples with Orthodoxy and a reverence for Russia's simpler past, Dugin has created a mythomoteur that constitutes a new identity for the Russian nation; that of the divinely-inspired unifying force to bring Russia and the rest of the world not to Orthodoxy, but to the Perennial Tradition. 


\section{Glossary}

Ariosophy - Also known as Armanism, Ariosophy is a term used to describe the racist and esoteric writings of mystics such as Guido von List (1848 - 1919) and Jorg Lanz von Liebensfels (1874 - 1954). Ariosophy can be understood as a broad philosophy that maintained that Aryans, or Nordic peoples, are scientifically and/or spiritually superior beings to nonAryans, particularly Jews. Ariosophy maintained that Aryan man originated in a fantastical northern continent known sometimes as Atlantis, Hyperborea or Thule. Organizing themselves in small lodges in Austria during the late nineteenth century and continuing into the interwar years, Ariosophists were fascinated with Germanic paganism and runes, seeing in the ancient practices of their Germanic ancestors a means of revitalizing modern Aryans. Ariosophy has been likened to a proto-Nazi ideology as its esoteric and mystical understanding of history combined to color much of the symbolism and eugenics policies of Nazism.

Conservative Revolution - The Conservative Revolution was a dissident rightist intellectual movement that originated during the Weimar Republic. While opposed to what it saw as the moral decadence of modern bourgeois values and the rising communist tide as the Nazis, Conservative Revolutionary thinkers such as Oswald Spengler (1880 - 1936) and Arthur Moeller van den Bruck (1876 - 1925) were also skeptical of the populism and demagoguery present in Nazism and other fascist movements. Conservative Revolutionaries tended to argue for a "Prussian" socialism in which traditional elites were restored but the nation would be united under an authoritarian ruler through revolutionary means. Unlike National Socialism, the Conservative Revolution espoused a cultural rather than biological anti-Semitism and a deep distrust of what they considered to be vulgar mass politics.

Fascism - A radical and extreme political ideology that combines a belief in the need for national rebirth, a renewal of cultural values and fervent ultranationalism. Typified by Nazi Germany and Fascist Italy, fascist movements have historically emphasized a vehement disdain 
for liberalism, Marxism, materialism, modernity and traditional elites. At the same time, fascism has often represented a modern reaction to modernity by further centralizing the state, displacing traditional elites, secularizing politics and culture, and introducing (pseudo-)scientific understandings of race.

Identitarianism - is a philosophical understanding of reality that holds that cultural and/or racial identity and its preservation are of the utmost importance. Originating in Cold War Europe, the term has become synonymous with the ideas espoused by Alain de Benoist and other members of the European New Right.

Modernity - For the purposes of this work, modernity is defined as the cultural and social value system that has existed since the advent of the Enlightenment in the Western World. These values include rationalism over mysticism, science and materialism over spirituality, economics over politics, and the importance of individual identity over organic communities. These values have become antithetical to New Right thinkers such as Alain de Benoist, Alexander Dugin and others who see modernity not as a positive, progressive step towards something better but a backwards slide into hedonist consumerism.

Mythomoteur - a term coined by the political scientist Anthony D. Smith, a mythomoteur is the constitutive complex of myths and symbols that create meaningful and lasting national identities. These myths, real or imagined, are utilized to fashion a multitude of local and regional identities into a larger national identity by linking the disparate regions through a shared history and images.

Particularism - a term often utilized by Alexander Dugin and like-minded thinkers who argue that the United States and its alleged global military-cultural hegemony threatens the individuality of various particular cultures and peoples. Particularism, then, is a call to preserve the individual characteristics of culturally distinct peoples, small and large, against what is considered to be the homogenizing effects of modern American consumerist and 
decadent culture.

Perennial Tradition - The Perennial Tradition, also known as Guénonian Traditionalism or simply Traditionalism, is the esoteric religious belief that virtually all the world's religions were once combined into a universal divine truth. This truth was encapsulated in a divinely-ordained human hierarchy in which the priest-king acted as a natural intercessor between inferior castes and the divine. However, with time and especially with the advent of modernity, sacred traditional values and practices such as traditional hierarchy and gender roles were inverted thus leading man only further away from the divine. Popularized by the mysticscholars René Guénon (1886 - 1951) and Julius Evola (1898 - 1974), Traditionalism is a pessimistic anti-modern (see: modernity) worldview that holds that Western society is in spiritual and moral decline. Traditionalism maintains that only through initiation in one of the religious paths that still have some connection to the primordial divine, such as Hinduism or a form of paganism, or through radical political, social and cultural reconstruction can man be reconnected with the natural, divinely-ordained order. Today, Alexander Dugin is perhaps one of the most known practitioners of Traditionalism.

Sacred Geography - A belief in the sacral nature of geographical space is present within the writings of both Ariosophists and Traditionalists. For instance, both Ariosophy and Tradition argue that during some primordial past a group of pure beings who held sacred wisdom lived in a far northern continent and later travelled and settled throughout the rest of the planet. However, unlike Ariosophists who claim that these settlers were racially and genetically superior Aryans, Traditionalists maintain that these beings were simply spiritually superior due to their advanced knowledge of the natural and divinely-ordained hierarchy that they then bestowed to the rest of humanity. The similarities between Ariosophist and Traditionalist definitions of sacred geography have led some scholars to conflate the two.

White Nationalism - A nationalist project that wishes to see the creation of either a 
large empire or collection of small states based on the premise that all racially white, or native European, peoples should live together. This term has frequently been utilized by White Power terrorists such as members of the violent group The Order as well as right wing thinkers such as Greg Johnson. 


\section{Bibliography}

\section{Primary Sources}

Aksakov, Ivan. “A Slavophile Statement.” Readings in Russian Civilization: Imperial Russia.

Ed. Thomas Riha. Chicago: University of Chicago Press, 1969.

Benoist, Alain de. On Being a Pagan. Atlanta: Ultra, 2005.

Benoist, Alain de. The Problems of Democracy. London: Arktos, 2011.

Bowden, Jonathan. “Jonathan Bowden - Julius Evola: The World’s Most Right-Wing

Thinker.” Youtube Video. Posted by TheArmenianNation. June 11, 2013.

https://www.youtube.com/watch?v=4YqKf3v2aPs.

Danilevsky, Nikolai. "The Slav Role in World Civilization." Readings in

Russian Civilization: Imperial Russia. Ed., Thomas Riha. Chicago: University of

Chicago Press, 1969.

Dugin, Alexander. “Alexander Dugin.” Introduction by Mark Sleboda. Identitär Idé 4 / Identitarian

Ideas 4. Youtube Video. Posted by Tankesmedjan Motpol. September 12, 2012.

https://www.youtube.com/watch?v=7X-o ndhSVA.

Dugin, Alexander. Eurasia Above All: Manifest of the Eurasianst Movement.

http://webcache.googleusercontent.com/search?q=cache:http://arctogaia.com/public/e ng/Manifesto.html.

Dugin, Alexander. The Fourth Political Theory. London: Arktos, 2012.

Dugin, Alexander. "From 3 political theories toward 4-th one," Youtube video. October 5, 2014. $<$ https://www.youtube.com/watch? $\mathrm{v}=\mathrm{Cpzxw} 2 \mathrm{u} 1 \mathrm{C} 8 \mathrm{Q} \# \mathrm{t}=1442>$.

Dugin, Alexander. From Sacred Geography to Geopolitics. http://evrazia.info/article/416 
Dugin, Alexander. Osnovi Geopolitiki. http://www.my.arcto.ru/public/osnovygeo/

Dugin, Alexander. Putin vs Putin: Vladimir Putin Viewed From the Right. London: Arktos, 2014.

Evola, Julius. Revolt Against the Modern World. Trans. Guido Stucco. Rochester: Inner Traditions International, 1995.

Evola, Julius. Notes on the Third Reich. Trans. E. Christian Koph. London: Arktos, 2013.

Evola, Julius. Fascism Viewed From the Right. Trans. E. Christian Koph. London: Arktos 2013.

Faye, Guillame. Why We Fight: Manifesto of the European Resistance. Trans. Michael O’Meara. London: Arktos, 2011.

Jakobson, Roman. Selected Writings VII, ed. Stephen Rudy. Berlin: Walter de Gruyter \& Co., 1985.

Johnson, Greg. Old Right vs. New Right. San Francisco: Counter-Currents Publishing ltd., 2013.

Johnson, Greg. “Americanism: A Cautionary Tale.” Counter-Currents. November, 2013. $<\underline{\text { http: } / / \text { www.counter-currents.com/2013/11/north-americanism-a-cautionary-tale/ }>}$.

Johnson, Greg. “Grandiose Nationalism,” Counter-Currents. February, 2015.

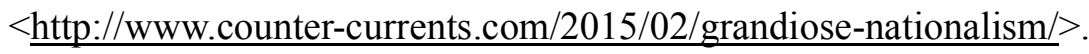

Malvicini, Giuliano Adriano. "Dugin Contra Racism.” Counter-Currents. September, 2014. $<\underline{\text { http://www.counter-currents.com/2014/09/dugin-contra-racism/ }}$.

Marsden, Victor trans. Protocols of the Learned Elders of Zion. Austin: RiverCrest Publishing, 2011.

McVan, Ron. Creed of Iron. Creative Space Publishing, 2012.

O’Meara, Michael. New Culture, New Right: Anti-Liberalism in Postmodern Europe. London: Arktos, 2013. 
O’Meara, Michael. "The Third Political Theory.” Counter-Currents. April, 2013. $<$ http://www.counter-currents.com/2013/04/the-third-political-theory/>.

Pipes, Richard trans. Karamzin's Memoir on Ancient and Modern Russia. Cambridge Massachusetts: 1959.

Pintér, Sándor. "Minister of Interior Bans Racist Conference." Website of the Hungarian

Government. September 29, 2014. <http://www.kormany.hu/en/ministry-ofinterior/news/minister-of-interior-bans-racist-conference $>$.

Pobedonostsev, Konstantin. "The Falsehood of Democracy.” Readings In Russian Civilization: Imperial Russia. Ed. Thomas Riha. Chicago: University of Chicago Press, 1969.

Pobedonostsev, Konstantin. Reflections of a Russian Statesment. London: Publsiher? 1898.

Schmitt, Carl. The Concept of the Political. Chicago: The University of Chicago Press, 2007.

Schmitt, Carl. The Crisis of Parliamentary Democracy. Cambridge: MIT Press, 1986.

Spengler, Oswald. The Decline of the West, vol 1. New York: Alfred A. Knopf, 1962.

Stolypin, Peter. "We Need a Great Russia." Readings in Russian Civilization: Imperial Russia. Ed. Thomas Riha. Chicago: University of Chicago Press, 1969.

Sunic, Tomislav. Against Democracy and Equality. London: Arktos, 2011.

Vernadsky, George. The Mongols and Russia. London: Oxford University Press, 1953.

Vernadsky, George. Kievan Russia. New Haven: Yale University Press, 1973.

Vernadsky, George. A History of Russia. New Haven: Yale University Press, 1969. 


\section{Secondary Sources}

Allensworth, Wayne. The Russian Question: Nationalism, Modernization and PostCommunist Russia. Lanham: Rowman \& Littlefield Publishers, 1998.

Allensworth, Wayne. ed. Marlene Laruelle, "Dugin and the Eurasian Controversy: Is Eurasianism 'Patriotic?"' Russian Nationalism and the National Reassertion of Russia. London: Routledge Taylor \& Francis Group, 2010.

Anderson, Bacon. Imagined Communities: Reflections on the Origins and Spread of Nationalism. London: Verso, 1991.

Bacon, Edwin ed., Evans, Alfred B., Henry,Laura A. Henry, and Mcintosh Sundstrom, Lisa. "The Church and Civil Society in Russia," Russian Civil Society: A Critical Assessment. London: M.E. Sharpe, 2006.

Ballinger, Pamela. History in Exile: Memory and Identity at the Borders of the Balkans. Princeton: Princeton University Press, 2003.

Barghorn, Frederick. Soviet Russian Nationalism. New York: Oxford University Press, 1956.

Baron, Salo W. The Russian Jew Under Tsars and Soviets. New York: Macmillan Publishing Co., 1964.

Brubaker, Rogers. Ethnicity Without Groups. Cambridge: Harvard University Press, 2004.

Clowes, Edith. Russia on the Edge - Imagined Geographies and Post-Soviet Identity, Ithaca and London: Cornell University Press, 2011.

Dunlop, John. The Faces of Contemporary Russian Nationalism. Princeton: Princeton University Press, 1983.

Dunlop John B. “Alexander Dugin's Foundations of Geopolitics.” The Fourth Political 
Theory: Beyond Left and Right but Against the Center.

http://www.4pt.su/en/content/aleksandr-dugin $\% \mathrm{E} 2 \% 80 \% 99$ s-foundations-geopolitics.

Ellis, Jane. The Russian Orthodox Church: A contemporary History. London: Publisher, 1986.

Fishman, Joshua. "Social Theory and Ethnography: Neglected Perspectives on

Language and Ethnicity in Eastern Europe." Ethnic Diversity and Conflict in Eastern

Europe. Ed. P. Sugar. Santa Barbara: ABC-Clio, 1980.

Freeze, Gregory. The Parish Clergy in Nineteenth-Centurty Russia: Crisis, Reform, Counter-Reform. Princeton: Princeton University Press, 1983.

Gardell, Mattias. Gods of the Blood: The Pagan Revival and White Separatism. Durham: Duke University Press, 2003.

Geertz, Clifford. The Integrative Revolution. London: Fontana, 1973.

Gellner, Ernst. Thought and Change. London: Weidenfeld and Nicolson, 1964.

Goodrick-Clarke. Nicholas. The Occult Roots of Nazism: Secret Aryan Cults and their Influence on Nazi Ideology. New York: New York University Press, 1992.

Goodrick-Clarke. Nicholas. Black Sun: Aryan Cults, Esoteric Nazism and the Politics of Idenity. New York: New York University Press, 2002.

Gregor, James A. Mussolini's Intellectuals: Fascist Social and Political Thought. Princeton: Princeton University Press, 2005.

Griffin, The Palingenetic Core of Fascist Ideology.

$<\underline{\text { https://www.libraryofsocialscience.com/ideologies/docs/the-palingenetic-core-of- }}$ generic-fascist-ideology/index.html >.

Hobsbawm, Eric and Ranger, Terrence. The Invention of Tradition. Cambridge: Cambridge University Press, 1983.

Hoffman, Stefani and Mendelsohn, Ezra ed. The Revolution of 1905 and Russia's Jews. Philadelphia: University of Pennsylvania Press, 2008. 
Huntington, Samuel P. Clash of Civilizations and the Remaking of World Order. New York: Simon and Schuster, 1996

Ismailov Eldar and Papava, Vladimer. Rethinking Central Eurasia. Johns Hopkins University, SAIS, 2010.

Klier, John D. and Lambroza, Shlomo ed. Pogroms: Anti-Jewish Violence in Modern Russian History. Cambridge: Cambridge University Press, 1992.

Korey, William. Russian Antisemitism, Pamyat, and the Demonology of Zionism. London: Routledge, 2004.

Lacqueur, Walter. Black Hundred: The Rise of the Extreme Right in Russia. New York: Harper Collins Publishers, 1993.

Lacquer, Walter. Russia and Germany. New York: Place of publication, 1987.

Laruelle, Marlene ed. Russian Nationalism and the National Reassertion of Russia. NewYork: Routledge, 2009.

Laruelle, Marlene. Russian Eurasianism: An Ideology of Empire.Johns Hopkins University Press, 2008.

Laruelle, Marlene. Russian Eurasianism: An Ideology of Empire. Trans. Mischa Gabowitsch. Washington D.C.: Woodrow Wilson Press, 2012.

Laruelle, Marlene. "The Orient in Russian Thought at the Turn of the Century." Russia Between East and West: Scholarly Debates on Eurasianism. Ed. Dmitry Schlapentokh. Leiden: Koniklijke Brill NV, 2007. Miller, David. The New Polytheism. New York: Harper and Row, 1974. Nolte, Ernst. The Three Faces of Fascism. London: Weidenfeld and Nicolson, 1965. Paxton, Robert O. The Anatomy of Fascism New York: Vintage Books, 2004. Payne, Stanley G. A History of Fascism 1914-1945. Madison: The University of Wisconsin Press, 1995. 
Renton, Dave. Fascism: Theory and Practice. London: Pluto Press, 1999.

Rawson, Don C. Russian Rightists and the Revolution of 1905. Cambridge: Cambridge University Press, 1995.

Rogger, Hans and Weber, Eugen, ed., "Russia." The European Right: A HistoricalProfile. Berkeley: University of California Press, 1965.

Rogger, Hans. Jewish Policies and Right Wing Politics in Imperial Russia. Berkeley: University of California Press, 1986.

Rogger, Hans. Russia in the Age of Modernisation and Revolution 1881-1917. London: Longman,1983.

Rossman, Vadim. Russian Intellectual Anti-Semitism in the Post-Communist Era. University of Nebraska Press, 2002.

Shenfield, Stephen D. Russian Fascism: Traditions, Tendencies, and Movements. New York: M.E. Sharpe, 2001.

Sedgwick, Mark. Against the Modern World: Traditionalism and the Secret Intellectual History of the Twentieth Century. Oxford: Oxford University Press, 2004.

Seton-Watson, Hugh. The Decline of Imperial Russia 1855-1914. New York: Frederick A. Praeger, 1962.

Shekhovtsov, Anton. “Aleksander Dugin's Neo-Eurasianism: The New Right à la Russe?” Religious Compass no. 3. Blackwell Publishing Ltd., 2009.

Smith, Anthony D. Nationalism. Cambridge: Polity Press, 2010.

Smith, Anthony D. The Ethnic Origins of Nations. New York: Basil Blackwell, 1986.

Smith, Anthony D. Nationalism and Modernism. London and New York: Routledge, 1998.

Stephan, John J. The Russian Fascists. New York: Publisher, 1978.

Sternhell, Zeev trans. David Maisel. The Birth of Fascist Ideology: From Cultural Rebellion to Political Revolution. Princeton: Princeton University, 1994. 
Umland, Andreas. "Post-Soviet 'Uncivil Society' and the Rise of Alexandr Dugin - A Case Study in Extraparliamentary Radial Right in Contemporary Russia. Ph.D dissertation, Trinity College-Cambridge, 2007.

Umland, Andreas and Shekhovtsov, Anton. "Is Alexander Dugin a Traditionalist? 'NeoEurasianism' and the Perennial Philosophy." The Russian Review 68 (October 2008 Umut Ozkirimli. Theories of Nationalism: A critical Introduction. New York: Palgrave Macmillan, 2010.

Welge, Jobst ed. Astradur Eysteinsson and Vivian Liska. "Fascist Modernism," Modernism. Vol. 2. Philadelphia: John Benjamins Publishing, 2007.

Yanov, Alexander. “The 'Enlightened' Nationalism of Lev Gumilev. Institute of Modern Russia December, 2012. <http://imrussia.org/en/society/613>. 